\title{
Water quality assessment in the Cherry Creek watershed: Patterns of nutrient runoff in an agricultural watershed
}

\author{
V.J. Alarcon and G.F. Sassenrath
}

\begin{abstract}
Access to safe, high quality water for consumption, agriculture, industry, and recreation is critically important. Continuous agricultural and mining activities have impaired the waters of the Grand Lake watershed in the central Great Plains region of the United States. The Grand Lake watershed encompasses portions of southeast Kansas, southwest Missouri, northwest Arkansas, and northeast Oklahoma, and drains into Grand Lake in northeast Oklahoma. The Cherry Creek watershed drains approximately $882.2 \mathrm{~km}^{2}(218,000 \mathrm{ac})$ of land in southeast Kansas and is a contributor of water to the Grand Lake watershed. This paper presents a water quality assessment in the Cherry Creek watershed, with an end toward mitigation of nonpoint source pollutants that are a major contributor to sediment and nutrient contaminants in Grand Lake.A hydrological model was developed using the Hydrological Simulation Program Fortran code and was updated, calibrated, and verified with measured data reported by US Geological Survey (USGS) and the Kansas Department of Health and Environment (KDHE). The model was extended to simulate water quality within the study area. Nitrate $\left(\mathrm{NO}_{3}^{-}-\mathrm{N}\right)$, total ammonia (TAM), total phosphorus (TP), and orthophosphate $\left(\mathrm{PO}_{4}^{3-}-\mathrm{P}\right)$ concentrations measured at the USGS stations were used to calibrate the model, and concentrations reported by KDHE at downstream locations were used to verify the model. Results indicate good performance of the hydrological model as tests of fitness were within levels established in previous studies (root-mean-squared-error to standard deviation ratio $[\mathrm{RSR}]<0.75 ;-30 \%<$ percentage bias $\left.[\mathrm{PBIAS}]<30 \% ; R^{2}>0.6 ; \mathrm{NS}>0.5\right)$. Nutrient measurements below the minimum quantifiable limit (MQL) hampered precise simulation of nutrient changes, though simulated values were acceptable in terms of ranges of contaminant concentration values and seasonal trends. The calibrated model was used to estimate the probability that nutrient levels would exceed established water quality criteria for rivers and streams. Concentration values of $\mathrm{NO}_{3}^{-}-\mathrm{N}$ and TAM are shown to be low for an agricultural watershed: $75 \%$ of the $\mathrm{NO}_{3}^{-}-\mathrm{N}$ and TAM concentrations are lower than $0.41 \mathrm{mg} \mathrm{L}^{-1}$. The probability of $\mathrm{NO}_{3}{ }^{-}-\mathrm{N}$ and TAM concentrations being toxic for aquatic communities is lower than $9 \%$. Although model-estimated $\mathrm{PO}_{4}^{3-}-\mathrm{P}$ concentrations were low in numerical value (ranging from 0 to $2.60 \mathrm{mg} \mathrm{L}^{-1}$ ), they could still promote eutrophication according to the accepted 0.05 mg L ${ }^{-1}$ criteria for maximum $\mathrm{PO}_{4}^{3-}-\mathrm{P}$ concentrations in streams. Concentrations of $\mathrm{PO}_{4}^{3-}-\mathrm{P}$ in Cherry Creek have a 30.4\% probability of exceeding that threshold. Extensive use of animal manure (primarily poultry) or manure from cattle grazing on pasture may account for the elevated levels of $\mathrm{PO}_{4}^{3-}-\mathrm{P}$ observed in the watershed. Although nutrient runoff from agricultural watersheds is anticipated to be a major contributor to elevated stream nutrient loads, these results indicate minimal contamination from Cherry Creek.
\end{abstract}

Key words: hydrological modeling-nitrate-nutrient modeling-orthophosphate-total ammonia-water quality

Secure access to clean, safe water is critical to support society. Water in many geographical areas is critically impaired due to sediment and nutrient contamination from both point and nonpoint sources. Soil and nutrient loss reduces the productive capacity of agricultural lands (Pierce et al. 1983; Pimentel 2006) and fills water reservoirs, reducing their capacity and creating potentially toxic algal blooms (Reilly 1999). This reduces the water security and creates potential trans-boundary contamination issues as negative environmental consequences of agricultural practices in one region or state impact neighbors (McKinney 2011).

The Grand Lake watershed encompasses portions of four states that drain into the Grand Lake in northeast Oklahoma. Extensive agricultural and mining operations in the watershed have severely impaired the waters of the region (OWRB 2001; Juracek 2008; Mignogna et al. 2012; Manders and Aber 2014; Dong et al. 2016). Grand Lake is a primary recreational area in northeast Oklahoma, but most of the watershed originates in other states. Of the rivers draining into Grand Lake, the Neosho River contributes one-half to three-fourths of all water, making it the primary contributor, and hence determinant, of pollutants in the system. The Middle Neosho watershed (MNW) begins in Neosho County in southeast Kansas and ends where the Neosho River crosses the Kansas-Oklahoma state line (Branson 1967). The MNW is the critical watershed draining the southeast area of Kansas into the Grand Lake watershed. As such, it is the transfer point of Kansas agricultural activities to Oklahoma water. The location of the MNW is representative of typical interstate and trans-boundary contamination cases that are becoming more relevant in the United States (DeLaune et al. 2006; McKinney 2011) and the rest of the world (Wouters 2013; Li et al. 2014), and will increase in intensity and negative impact as environmental consequences heighten.

To avoid potential litigious actions that have occurred in the area (City of Tulsa vs. Tyson Foods 2003) and address the critical contamination issues of water supplies, Kansas and Oklahoma have coordinated the development of Watershed Restoration and Protection Strategy plans (GLCWAF 2008; MNW 2011) that identify critical areas within adjoining watersheds and develop preliminary plans for remediation. These management plans emphasize the essential

Vladimir J. Alarcon is an assistant professor at the Civil Engineering School, Diego Portales University, Santiago, Chile. Gretchen F. Sassenrath is an associate professor of agronomy at the Southeast Research and Extension Center, Kansas State University, Parsons, Kansas, United States. 
need to identify and quantify all pollutant sources in the basin, including both nonpoint and point sources, through the use of computer models that incorporate data on soil type, topography, land use practices, and climate for estimation of pollutant loadings and transport throughout the watersheds of the region (GLCWAF 2008). The highest priority impairments in the Neosho River watershed are nutrients, sediments, and bacteria. The MNW does not meet state water quality standards and fails to achieve aquatic system goals related to habitat and ecosystem health. It has been designated a priority for restoration (MNW 2011).

Land use in the MNW is primarily intensive agricultural production, with historical mining activity. Agricultural production includes row crop and grain production, and cattle production on pasture. Most of the crop production relies on conventional tillage for weed control and seed bed preparation. Although there are some animal confinement operations (swine, poultry, or beef cattle feedlots) within the watershed, most of the animal manures are imported from the extensive poultry production facilities in neighboring states (Tomlinson et al. 2014). Average annual rainfall in excess of $100 \mathrm{~cm}$ (39.3 in) exacerbates nutrient and sediment erosion from fields and pastures; climate models predict future rain events will increase in amount and intensity (IPCC 2007). Significant agricultural production in the area continues to erode soil resources and impair the watershed.

Cherry Creek is one of the main tributaries to the Neosho River (figure 1), located in the southeast MNW. The Cherry Creek watershed encompasses primarily agricultural lands, with no major urban areas. Historical mining activities have left strip mine pits that have filled with rain to form strip pit wetlands. The Middle Neosho Watershed Restoration and Protection Strategy study (MNW 2011) lists the Cherry Creek watershed as a targeted area for agricultural best management practices (BMPs) to meet sediment and nutrient load reductions. The Grand Lake Watershed Plan (GLCWAF 2008) also lists Cherry Creek as a high-priority stream for a total maximum daily load (TMDL) study oriented toward reducing nutrient and sediment loads that cause the stream to be listed for a dissolved oxygen (DO) TMDL. Implementation of conservation practices may reduce nutrient and sediment losses within the watershed (Parajuli et al. 2013; Alarcon and Sassenrath 2015; Padedda et al. 2015), and improve water quality in the Cherry Creek watershed, as well as waters of the region.

A TMDL report (KDHE 2002) prioritized the development of a DO TMDL for Cherry Creek based on several observations of low DO levels during a 10-year study period (1991 to 2001). It was recommended that the biological oxygen demand (BOD) be allocated to achieve concentrations lower than $2.65 \mathrm{mg} \mathrm{L}^{-1}$ in order to comply with the $5 \mathrm{mg} \mathrm{L}^{-1}$ standard for DO (USEPA 2002). Since nutrient concentrations were reported to be at very low levels $(<0.89 \mathrm{mg}$ $\mathrm{L}^{-1}$ ), the low DO episodes were attributed to biological contamination (BOD). The primary land use of the region is agricultural (crops and pasture). The use of chemical and manure fertilizers is extensive, and if BMPs for fertility management are not followed, fertilizers and animal manure can contribute significantly to nutrient pollution in water bodies. A comprehensive approach to nutrient loss control has been identified as critical to mitigate eutrophication of fresh waters (Tomer et al. 2013). Continuous water quality monitoring in conjunction with event-based water sampling collection may reveal the actual contribution of nonpoint source runoff to nutrient concentrations in the Cherry Creek watershed. However, this approach is time consuming, labor intensive, and expensive in terms of laboratory analysis. Water quality modeling may provide an alternative tool to assess nonpoint source nutrient contributions.

This study was undertaken to develop an accurate, robust method of tracking nutrient and sediment sources in the MNW using a critical subwatershed within the MNW, Cherry Creek, as a model. We use hydrological and water quality modeling to estimate nitrate-nitrogen $\left(\mathrm{NO}_{3}^{-}-\mathrm{N}\right)$, total ammonia (TAM) as $\mathrm{N}$ (comprising $\mathrm{NH}_{3}$ or nonionized ammonia, and ionized ammonia, i.e., ammonium, $\mathrm{NH}_{4}^{+}$), total phosphorus (TP), and orthophosphate $\left(\mathrm{PO}_{4}^{3-}-\mathrm{P}\right)$ concentrations for streams within the Cherry Creek watershed for an extended period of time (1976 to 2008). Based on the nutrient concentrations estimated by the model and an analysis of current agricultural practices in the area, we explore potential factors contributing to water quality issues in the area. The water quality of the stream is also cat- egorized based on a compounded water quality indicator. This research contributes to the ongoing interstate collaboration to improve the water quality within the Grand Lake watershed, and improve water security for the region and the nation. This modeling tool will allow us to delineate environmentally sensitive areas and identify potentially critical production management practices that can be implemented or altered to reduce nutrient loss from agronomic fields.

\section{Materials and Methods}

Study Area. The Cherry Creek catchment and stream drains approximately $882.2 \mathrm{~km}^{2}$ $(218,000 \mathrm{ac})$ in southeastern Kansas (figure 1). Historical annual average stream flows at USGS gauge station 07184300 (figure 2) range from 1.50 to $1.72 \mathrm{~m}^{3} \mathrm{~s}^{-1}\left(53\right.$ to $60.7 \mathrm{ft}^{3}$ $\left.\mathrm{sec}^{-1}\right)$. Recorded weather data at the National Weather Service station at Columbus, Kansas (figure 2), report an average total annual precipitation of $1,131 \mathrm{~mm}$ (44 in), with a range from $601 \mathrm{~mm}$ (23.7 in) to $1,676 \mathrm{~mm}$ (66 in). The Cherry Creek catchment physiography is typical of an agricultural watershed and similar to surrounding watersheds in the Middle Neosho River hydrological unit (USGS HUC 11070205). The Cherry Creek watershed is a contributor of water to the Neosho River, and hence to Grand Lake, Oklahoma. Hydrological and water quality processes modeled in Cherry Creek could be extrapolated to neighboring hydrological units.

Agricultural Practices in the Area. Most agricultural practices in the watershed are conventional, large-scale (8 to 12 row equipment) crop production. The crop rotation system produces three crops in two years (corn [Zea mays L., March to August])/ winter wheat [Triticum aestivum L., October to June]/soybeans [Glycine max L., June to November]), with some rotation to sorghum (Sorghum bicolor L.) or other small grains. Row crops are commonly planted in $76 \mathrm{~cm}$ (30 in) rows with commercial planting equipment. Wheat is commonly drilled. The management includes surface tillage $(15 \mathrm{~cm}$ [6 in] deep, disk or field cultivator) prior to planting corn or winter wheat; soybeans are more commonly planted no-till immediately after wheat harvest. Fertility is commonly performed by knifing in urea at recommended rates for the area (corn: $68 \mathrm{~kg} \mathrm{~N}$ [150 lb N]; wheat: $45 \mathrm{~kg} \mathrm{~N}$ [100 lb N]); phosphorus (P; $21 \mathrm{~kg}[46 \mathrm{lb}])$ and potassium (K; $20 \mathrm{~kg}$ [45 lb]) are applied at recommended rates to all 
crops prior to planting (Leikam et al. 2003). Micronutrients are usually abundant in the soil and not commonly added. Poultry litter, imported from confinement poultry operations in neighboring states, is often used to supplement fertility, especially $\mathrm{P}$ (Thomlinson et al. 2014). Herbicides, insecticides, and fungicides are applied as needed to control pests and diseases. Because of the high rainfall common to the area, fungicides are commonly used, especially in wheat production (Bockus et al. 2001).

The agricultural practices described above were introduced to the model in the subroutines related to nutrient loading and timing of fertilization and harvesting. The level of hydrological and water quality modeling employed in this study was at a watershed level, and hence did not utilize different field-scale operations such as tillage, planting, or other field operations.

Hydrological Code and Geographic Information Systems Software. Hydrological modeling of the Cherry Creek watershed was performed with the Hydrological Simulation Program Fortran (HSPF) (Bicknell et al. 1997). The HSPF code was developed by the Environmental Research Laboratory in Athens, Georgia, and most of the continued development has been sponsored by the USGS Water Resources Division in Reston, Virginia (Bicknell et al. 1997). The HSPF code is a computer model designed for simulation of nonpoint source watershed hydrology and water quality. Time-series of meteorological data and digital maps characterizing land use, soil, and topography are used to estimate stream flows and pollutant concentrations. The model simulates interception of rainfall, soil moisture, surface runoff, interflow, base flow, snowpack depth and water content, snowmelt, evapotranspiration, and groundwater recharge. Simulation results are provided as time-series of runoff, sediment load, and nutrient and pesticide concentrations, along with time-series of water quantity, at any point in a watershed. Additional software (Watershed Data Management Utility [WDMUtil; Hummel et al. 2001] and Generation Scenarios [GenScn; Kittle et al. 1998]) is used for data preprocessing and postprocessing, and for statistical and graphical analysis of input and output data (Alarcon and O'Hara 2010). The Better Assessment Science Integrating Point and Nonpoint Sources, BASINS 4.1, GIS system (USEPA

\section{Figure 1}

Middle Neosho and Cherry Creek watersheds. The Middle Neosho watershed (MNW) is located in southeast Kansas, near the borders of Oklahoma and Missouri. The Cherry Creek watershed is in the southeast portion of the MNW. Grand Lake (Oklahoma) receives waters from Cherry Creek via the Neosho River.

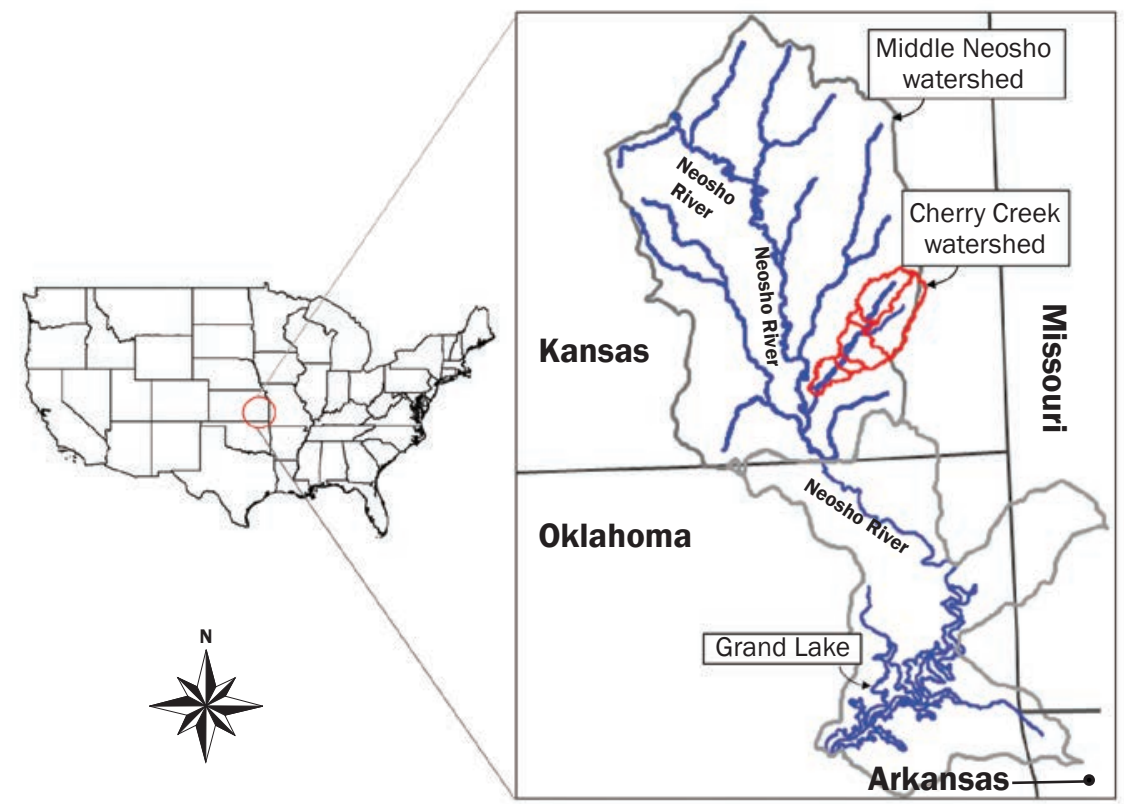

\section{Figure 2}

Streams, outlet, and watershed delineation of the Cherry Creek watershed. The seven subwatersheds within the Cherry Creek watershed are identified, along with the US Geological Survey (USGS) gage stations near West Mineral and Hallowell. The Kansas Department of Health and Environment (KDHE) sampling location near Faulkner is near the confluence of Cherry Creek and the Neosho River. The National Weather Service meteorological station in Columbus is to the southeast of the Cherry Creek watershed.

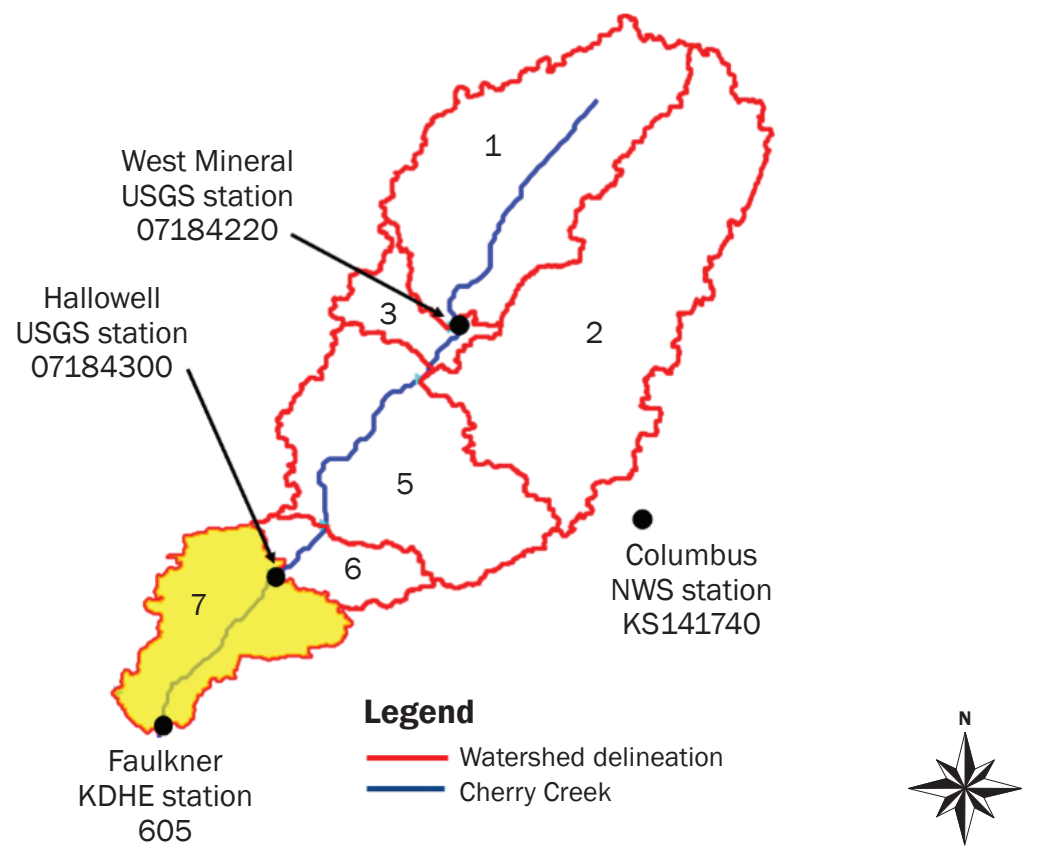


2013) was used for downloading basic data and delineating the watershed in this study. The creation of the initial HSPF models was performed using the WinHSPF interface in BASINS 4.1. ArcGIS 10.1 (ESRI, Redlands, California) was used for performing operations not available in the BASINS 4.1 system (zonal statistics, etc.). Additional statistical analysis was performed in MS Office Excel (Microsoft, Inc., Albuquerque, New Mexico).

Table 1 summarizes the meteorological data sets used for setting up the model and the data sets used for calibration and verification of the model outputs. Records of hourly precipitation, solar radiation, air temperature, wind, potential evapotranspiration, and dew point corresponding to National Weather Service (NWS) station KS141740 (figure 2) were downloaded from the BASINS Meteorological database (USEPA 2008). The download of this data set and several other basic data sets is performed through the BASINS system when initializing the spatial modeling portion of the modeling effort (Ouyang et al. 2013). Data measured from August 1, 1948, to December 31, 2008, were downloaded.

Stream flow and water quality data from two USGS stations (07184300 at Hallowell, and 07184220 at West Mineral, figure 2) were used for calibration and verification of model outputs, respectively. Daily stream flow records were not available continuously for the study period, but rather for several discrete time periods as detailed in table 1 . These time-series were compared statistically to the stream flow model output until good statistical fit was achieved.

Changes in collection locations and intervals resulted in very little available water quality data for model development, calibration, and verification. Discrete $\mathrm{NO}_{3}^{-}-\mathrm{N}, \mathrm{TAM}$ as $\mathrm{N}$, and TP (all the forms of $\mathrm{P}$, dissolved or particulate, organic or inorganic, TP as $\mathrm{P}$ ) data collected during 1977 and 1978 at both locations were used to calibrate and verify $\mathrm{NO}_{3}^{-}-\mathrm{N}$, TAM, and $\mathrm{P}$ concentration values estimated by the model. An additional 21 records of water quality data $\left(\mathrm{NO}_{3}{ }^{-} \mathrm{N}, \mathrm{TAM}\right.$, and $\mathrm{PO}_{4}^{3-}-\mathrm{P}$, the main constituent in fertilizers) collected at a Kansas Department of Health (KDHE) station located downstream near Faulkner, Kansas (figure 2), were used to further ascertain the validity of water quality concentration values output by the model.

Topographical, Land Use, and Soil Data Sets. Topographical and land use data sets, preprocessed for BASINS and stored on a US
Environmental Protection Agency (USEPA) server for download (USEPA 2008), were used for initial parameterization of the model for Cherry Creek. The National Elevation Data (NED) data set was downloaded for characterizing the topography of the Cherry Creek watershed. The NED data set has a spatial resolution of $30 \mathrm{~m}(98.4 \mathrm{ft})$ and is provided with elevation values in centimeters. The use of this data set is facilitated by the BASINS GIS system as it is automatically reprojected from geographical coordinates to the coordinate system in which the BASINS project is established. In this research, all geoprocessing and modeling operations were performed in Universal Transverse Mercator (UTM), Zone 15 North.

The National Land Cover Data (NLCD) 2001 derived from the early to mid-1990s Landsat Thematic Mapper satellite data is a 21-class land cover classification scheme applied consistently across the United States (Homer et al. 2007). The spatial resolution of the data is $30 \mathrm{~m}$ (98.4 ft) and was reprojected from its original Albers Conic Equal Area projection to UTM Zone 15 North.

Moriasi and Starks (2010) found that there were no significant differences in statistical indicators from hydrological modeling between the higher resolution Soil Survey Geographic Database (SSURGO) and the lower resolution State Soil Geographic Database (STATSGO). In this research we used the STATSGO soil characterization.

Land Use Change in the Area. Model development was performed using the NLCD 2001 land use digital raster. The validation of the model output was done for dates ranging from 1991 to 2008. Although it would be possible to compare the results to the NLCD 1992 data set, a direct comparison of this data set with any subsequent NLCD data sets is not suggested due to changes in the methods of legend and map development (MRLC 2016). Therefore, to verify that the land cover map was still valid for simulation dates close to 2008, the "NLCD 2001 to 2011 Land Cover Change" digital raster (USGS 2014) was used to determine if significant land use changes have occurred that would invalidate the model output. This data set is a raster layer in which the spectral signature of each pixel has been identified as dissimilar when comparing NLCD 2001 to NLCD 2011 Land Cover products. Pixels identified as unchanged contain a generic value of zero. The raster layer is the result of the application of a new comprehensive change detection method that includes spectral-based change detection algorithms able to extract change information from pairs of Landsat images (Jin et al. 2013).

The polygon representing the Cherry Creek watershed was overlaid on the NLCD Land Cover Change raster to assess land use change in the area of study. Standard zonal statistics tools were used to identify the number of pixels that underwent spectral signature change from 2001 to 2011 (i.e., land use change) and also to count the pixels without change.

Hydrological and Water Quality Modeling. Two model applications were developed in this research, each designed with different watershed delineations. The initial model described a hydrological model for upper Cherry Creek (subbasins 1, 2, 3, 5, and 6; figure 2) and was calibrated for stream flow comparing simulated output to measured data reported at USGS station 07184300 (Hallowell). Six years of measured data were available at this station (September 2, 1976, to September 30, 1982; table 1). After the statistical fit analysis indicated good agreement between simulated and measured stream flows at Hallowell, the model output was compared against measured data collected at USGS station 07184220 (West Mineral). This process was repeated until statistical fit between simulated and measured hydrology data at both stations was good. The comparison at West Mineral was performed for several different time periods from 1976 to 1979 since daily stream flow data were only available in discrete intervals (table 1). The HSPF parameters used for hydrological calibration were the following: INFILT (index to the infiltration capacity of the soil), LZSN (lower zone nominal storage), INTFW (interflow inflow parameter), LZETP (lower zone evapotranspiration), KVARY (groundwater recession flow), IRC (interflow recession parameter), and UZSN (upper zone nominal storage), defined in table 2 .

The development of the water quality portion of the model was performed in a similar fashion, although the limited availability and quality of measured data did not allow full statistical comparison of simulated and measured data. Nitrate-N, TAM, and TP concentrations measured at Hallowell (USGS 07184300) for several dates between January of 1977 and March of 1978 (table 1) were used to calibrate the model. The minimum 
Table 1

Meteorological, stream flow, and water quality data used for hydrological and water quality modeling of the Cherry Creek watershed.

\begin{tabular}{|c|c|c|c|c|}
\hline Data set & Station & Location & Records dates & Use \\
\hline Precipitation & NWS KS141740 & Columbus, Kansas & Aug. 1, 1948, to Dec. 31, 2009 & Input data \\
\hline Evapotranspiration & NWS KS141740 & Columbus, Kansas & Aug. 1, 1948, to Dec. 31, 2009 & Input data \\
\hline Wind & NWS KS141740 & Columbus, Kansas & Aug. 1, 1948, to Dec. 31, 2009 & Input data \\
\hline Air temperature & NWS KS141740 & Columbus, Kansas & Aug. 1, 1948, to Dec. 31, 2009 & Input data \\
\hline Dew point & NWS KS141740 & Columbus, Kansas & Aug. 1, 1948, to Dec. 31, 2009 & Input data \\
\hline Solar radiation & NWS KS141740 & Columbus, Kansas & Aug. 1, 1948, to Dec. 31, 2009 & Input data \\
\hline Stream flow & USGS 07184300 & Hallowell, Kansas & Sept. 2, 1976, to Sept. 30, 1982 & Hydrological calibration \\
\hline Stream flow & USGS 07184220 & W. Mineral, Kansas & $\begin{array}{l}\text { Oct. } 20,1976 \text {, to Nov. } 16,1976 \\
\text { Apr. } 24,1977 \text {, to Sept. } 30,1977 \\
\text { Oct. } 18,1977 \text {, to June } 23,1978 \\
\text { July } 19,1978 \text {, to Oct. } 17,1978 \\
\text { Nov. } 14,1978 \text {, to Jan. } 3,1979 \\
\text { Apr. } 11,1979 \text {, to May } 16,1979\end{array}$ & Hydrological verification \\
\hline
\end{tabular}

\begin{tabular}{|c|c|c|c|c|}
\hline $\begin{array}{l}\text { Water quality } \\
\left(\mathrm{NO}_{3}{ }^{-} \mathrm{N}, \mathrm{TAM}, \mathrm{PO}_{4}{ }^{3-}-\mathrm{P}\right)\end{array}$ & USGS 07184300 & Hallowell, Kansas & $\begin{array}{l}11 \text { to } 29 \text { records between January of } \\
1977 \text { to March of } 1978 \text { depending on } \\
\text { WQ constituent }\end{array}$ & Water quality calibration \\
\hline $\begin{array}{l}\text { Water quality } \\
\left(\mathrm{NO}_{3}{ }^{-} \mathrm{N}, \mathrm{TAM}, \mathrm{PO}_{4}{ }^{3-}-\mathrm{P}\right)\end{array}$ & USGS 07184220 & W. Mineral, Kansas & $\begin{array}{l}15 \text { to } 29 \text { records between January of } \\
1977 \text { to March of } 1978 \text { depending on } \\
\text { WQ constituent }\end{array}$ & Water quality calibration \\
\hline $\begin{array}{l}\text { Water quality } \\
\left(\mathrm{NO}_{3}{ }^{-} \mathrm{N}, \mathrm{TAM}, \mathrm{PO}_{4}{ }^{3-}-\mathrm{P}\right)\end{array}$ & KDHE 605 & Near Faulkner, Kansas & 21 records between 1991 and 2008 & Water quality verification \\
\hline
\end{tabular}

quantifiable limit (MQL) is the concentration or amount below which the analytical laboratory methods cannot operate with an acceptable level of precision (Bernal 2014; USEPA 2010). Since 11 to 29 measured data records were reported at this station (with the actual number of records dependent on the specific water quality parameter), and several of those concentration values were below the MQL, the calibration and subsequent verification processes focused on replicating trends and range of concentration values as much as fitting simulated data to measured data when these data were available. Sensitivity analysis was one of the criteria followed during calibration. Alarcon and Sassenrath $(2015,2016)$ provided the basis for the calibration process that also looked for parameter values that made physical and chemical sense and were within ranges recommended by the literature. Verification of the model outputs were performed comparing $\mathrm{NO}_{3}^{-}-\mathrm{N}$, TAM, and TP simulated output to measured data at the West Mineral USGS station (USGS 07184220). The following HSPF water quality parameters (Ouyang et al. 2015) were used during the water quality calibration process: $\mathrm{MON}_{\text {}}$ ACCUM (monthly value of accumulation rates of nutrients at start of each month), MON-SQOLIM (monthly values limiting storage of nutrients at start of each month), MON-IFLW-CONC (monthly value of nutrient concentrations in interflow outflow at start of month), MON-GRND-CONC (monthly value of nutrient concentrations in groundwater outflow at start of month), ALNPR (fraction of $\mathrm{N}$ requirements for phytoplankton growth satisfied by $\mathrm{NO}_{3}^{-}-\mathrm{N}$ ), MALGR (maximal unit algal growth rate for phytoplankton), and POTFW (wash-off potency factor) (table 2).

The KDHE collected additional and updated water quality data downstream from the USGS Hallowell station at KDHE Station 605 near Faulkner (figure 2). Since the model for upper Cherry Creek did not cover this downstream location, a second hydrological and water quality model covering both the upper and lower Cherry Creek watersheds (subbasins 1, 2, 3, 5, 6, and 7; figure 2) was developed for modeling flow and water quality estimations at KDHE Station
605. The new hydrological delineation of the area produced an additional subbasin 4 that was external to the Cherry Creek catchment area, and hence was not included in the HSPF model. Hydrological and water quality parameters were extrapolated to this bigger watershed model. Meteorological, land use (NLCD 2001), and topographical (NED) data sets were the same as in the previous model, but covered a larger geographical area and extended temporal meteorological time-series. However, to verify if the extrapolation of hydrological and water quality parameters was correct, the locations of the USGS stations at Hallowell and West Mineral were set up to be catchment exits so that the watershed delineation of the bigger model included them as catchment exits. In this way a comparison of the output of both models, in terms of stream flow and water quality estimations, was possible.

Statistical Indicators of Fit, Probability of Exceedance, and Water Quality Indicator. The use of indicators of fit in hydrological and water quality modeling is useful for evaluating how the model-simulated output 
Table 2

Parameters used in hydrological and water quality calibration of the Cherry Creek watershed model.

\begin{tabular}{|c|c|c|}
\hline Calibration & Definition & Range (mg L-1) \\
\hline \multicolumn{3}{|l|}{ Hydrological calibration } \\
\hline INFILT & Index to the infiltration capacity of the soil & 0.12 to 0.18 \\
\hline LZSN & Lower zone nominal storage & 3.00 to 5.50 \\
\hline INTFW & Interflow inflow parameter & 2.00 to 4.00 \\
\hline LZETP & Lower zone evapotranspiration & 0.40 to 0.60 \\
\hline KVARY & Groundwater recession flow & 1.90 to 2.10 \\
\hline IRC & Interflow recession parameter & 0.46 to 0.48 \\
\hline UZSN & Upper zone nominal storage & 0.90 to 1.20 \\
\hline \multicolumn{3}{|c|}{ Water quality calibration } \\
\hline MON_ACCUM & Monthly value of accumulation rates of nutrients at start of each month & $\begin{array}{l}\text { TAM: } 0.007 \text { to } 0.01 \\
\mathrm{NO}_{3}{ }^{-}-\mathrm{N}: 0.01 \text { to } 1.05 \\
\mathrm{PO}_{4}{ }^{3-}-\mathrm{P}: 0.003 \text { to } 0.01\end{array}$ \\
\hline MON-SQOLIM & Monthly value limiting storage of nutrients at start of each month & $\begin{array}{l}\text { TAM: } 0.005 \text { to } 0.02 \\
\mathrm{NO}_{3}{ }^{-}-\mathrm{N}: 0.07 \text { to } 3.16 \\
\mathrm{PO}_{4}{ }^{3-}-\mathrm{P}: 0.004 \text { to } 0.02\end{array}$ \\
\hline MON-IFLW-CONC & Monthly value of nutrient concentrations in interflow outflow at start of month & $\begin{array}{l}\text { TAM: } 0.03 \text { to } 0.80 \\
\mathrm{NO}_{3}{ }^{-}-\mathrm{N}: 0.10 \text { to } 3.50 \\
\mathrm{PO}_{4}{ }^{3-}-\mathrm{P}: 0.009 \text { to } 0.10\end{array}$ \\
\hline MON-GRND-CONC & Monthly value of nutrient concentrations in groundwater outflow at start of month & $\begin{array}{l}\text { TAM: } 0.04 \text { to } 1.50 \\
\mathrm{NO}_{3}{ }^{-} \mathrm{N}: 0.05 \text { to } 0.50 \\
\mathrm{PO}_{4}{ }^{3-} \mathrm{P}: 0.005 \text { to } 1.0\end{array}$ \\
\hline ALNPR & Fraction of nitrogen requirements for phytoplankton growth satisfied by nitrate & 0.60 to 0.80 \\
\hline MALGR & Maximal unit algal growth rate for phytoplankton & 0.40 to 0.60 \\
\hline POTFW & Wash-off potency factor & $\begin{array}{l}50 \text { (Alarcon and } \\
\text { Sassenrath 2015) }\end{array}$ \\
\hline
\end{tabular}

Notes: TAM = total ammonia. $\mathrm{NO}_{3}{ }^{-}-\mathrm{N}=$ nitrate-nitrogen. $\mathrm{PO}_{4}{ }^{3-}-\mathrm{P}=$ orthophosphate.

compares to measured data. While the coefficient of determination $\left(R^{2}\right)$ is commonly used for assessing statistical fit, additional recommended tests include quantifying statistical error (root-mean-squared-error to standard deviation ratio [RSR]); estimating bias of simulated data with respect to measured data (percentage bias [PBIAS]); and using the Nash-Sutcliffe coefficient (NS) to assess how well the plot of observed versus simulated data fits the 1:1 line (Moriasi et al. 2007). All four standard statistical indicators of fitness (Moriasi et al. 2007) are used in this research, as outlined in table 3 .

The calculation of probabilities of exceedance for the water quality variables included in this study are performed using the standard approach detailed in Searcy (1959) and summarized in table 3 . Since the model was trained with limited nutrient data, and long-term simulations are required for the calculation of exceedance probabilities, confidence bounds are calculated for the exceedance probability curve. For this, the 32-year continuous daily water quality simulation (1976 to 2008) was considered to be a series of 32 realizations of water quality events. The empirical distribution function of these realizations is considered an estimate of the true water quality distribution function. The uncertainty of this estimate is quantified in terms of $1-\alpha$ confidence bands. Since the variance of the distribution is not known and the number of samples is only 32 , the $t$ distribution with $\alpha=0.01$ (i.e., $t=$ 2.744) was used to calculate the upper and lower confidence bands of the mean probability of exceedance.

A water quality indicator (WQI) is used to summarize and classify the water quality of Cherry Creek and other water bodies in the Cherry Creek watershed with a single numerical value (Terrado et al. 2010). The WQI index ranges between 0 (worst water quality) and 100 (best water quality) in five categories:

1. $0<\mathrm{WQI}<44$ : poor water quality, almost always threatened or impaired;

2. $44.1<\mathrm{WQI}<64$ : marginal water quality, water quality is frequently threatened or impaired;

3. 64.1 < WQI < 79: fair water quality, usually protected but occasionally threatened or impaired;

4. 79.1 < WQI < 94: good water quality, the water body is protected, with only a minor degree of threat or impairment; and

5. $94.1<\mathrm{WQI}<100$ : excellent water quality, the water body is protected with a virtual absence of threat or impairment.

The WQI was chosen for this study because it is a flexible index that can be used with several different parameters. Since three water quality variables are modeled and/or simulated in this research $\left(\mathrm{NO}_{3}{ }^{-} \mathrm{N}\right.$, TAM, and $\left.\mathrm{PO}_{4}^{3-}-\mathrm{P}\right)$, each with specific water 


\section{Table 3}

Formulae for calculation of indicators of fit, probability of exceedance, water quality indicator (WQI), and cumulative WQI deviation from mean.

\begin{tabular}{|c|c|}
\hline Statistic & Formula \\
\hline \multicolumn{2}{|l|}{ Indicators of fit } \\
\hline $\begin{array}{l}\text { Root-mean-squared-error to } \\
\text { standard deviation ratio }\end{array}$ & $R S R=\frac{R M S E}{S T D E V_{\text {Obs }}}=\frac{\sqrt{\sum_{i=1}^{n}\left(Y_{i}^{\text {Obs }}-Y_{i}^{\text {Sim }}\right)^{2}}}{\sqrt{\sum_{i=1}^{n}\left(Y_{i}^{\text {Obs }}-Y_{i}^{\text {Mean }}\right)^{2}}}$ \\
\hline Percentage bias & PBIAS $=\frac{\sum_{i=1}^{n}\left(Y_{i}^{\mathrm{Obs}}-Y_{i}^{S i m}\right) \times 100}{\sum_{i=1}^{n}\left(Y_{i}^{\mathrm{Obs}}\right)}$ \\
\hline Coefficient of determination & $R^{2}=\frac{\sum_{i=1}^{n}\left(Y_{i}^{\text {Sim }}-Y_{i}^{\text {Mean }}\right)^{2}}{\sum_{i=1}^{n}\left(Y_{i}^{\text {Obs }}-Y_{i}^{\text {Mean }}\right)^{2}}$ \\
\hline Nash-Sutcliffe efficiency & $N S=1-\frac{\sum_{i=1}^{n}\left(Y_{i}^{\text {Obs }}-Y_{i}^{\text {Sim }}\right)^{2}}{\sum_{i=1}^{n}\left(Y_{i}^{\text {Obs }}-Y_{i}^{\text {Mean }}\right)^{2}}$ \\
\hline Probability of exceedance & $P=\frac{m}{n+1} \times 100$ \\
\hline Water quality indicator & $W Q I=100-\left(\frac{\sqrt{F_{1}^{2}+F_{2}^{2}+F_{3}^{2}}}{1.732}\right)$ \\
\hline $\begin{array}{l}\text { Cumulative WQI deviation } \\
\text { from the mean }\end{array}$ & Cumulative $W Q I$ deviation $=\sum \frac{\left(W Q I_{j, k}-\widehat{W Q I}_{k}\right)}{\widehat{W Q I}_{k}}$ \\
\hline \multicolumn{2}{|l|}{ Notes: } \\
\hline \multicolumn{2}{|c|}{ 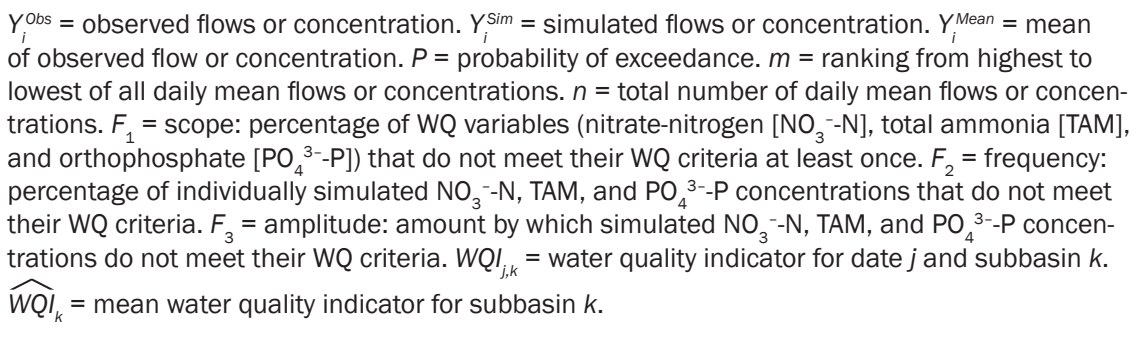 } \\
\hline
\end{tabular}

quality criteria, the WQI approach was wellsuited for classifying the water quality of the Cherry Creek watershed. Table 3 summarizes the formulae involved in the calculation of WQI. In addition to the calculation of WQI for each subbasin, cumulative WQI deviations from the mean were also calculated for each subbasin (table 3). This cumulative indicator shows the WQI evolution for each subbasin through time, and also allows comparison of water quality status between subbasins. The smaller the cumulative WQI values (in the algebraic sense), the better the water quality of the surface water. Since cumulative values are calculated relative to the mean WQI, they can be negative (i.e., larger negative values mean better water quality). Conversely, larger positive values of cumulative WQI deviation indicate poorer water quality.

\section{Results and Discussion}

Land Use/Land Cover and Change. The Cherry Creek watershed is primarily an agricultural watershed, with $78 \%$ of the watershed dedicated to agricultural activities (52\% croplands and $26 \%$ pasture) according to the NLCD 2001 digital raster (figure 3). Total urban area covers less than $6 \%$, and other land use/land cover categories are minimal. Forests, open water, and wetlands are the only other significant land cover in the watershed covering $7 \%, 1.4 \%$, and $5.5 \%$, respectively (in figure 3 , open water and wetlands were represented as only one land use category). The wetlands are abandoned strip pits that have filled in with trees and shrubs and become forested wetlands. Although these wetlands could absorb excess nutrients from surrounding croplands or pasture lands, poten- tially reducing the pollutant loads to Cherry Creek, their effect was considered to be minimal as more than two-thirds of the watershed surface dedicated to agricultural activities are located either downstream from these forested wetlands or in subwatersheds that do not contain any of those woody wetlands.

Measured water quality and stream flow data are available from 1976 to 2008. To better match this data set, the NLCD 2001 digital land use map was the most appropriate for model development and calibration. A verification of the suitability of the NLCD 2001 digital raster for characterizing land use throughout the 2001 to 2011 decade is shown in table 4. Zonal statistics of the entire Cherry Creek watershed model showed that more than $99.6 \%$ of the spectral signatures of pixels were unchanged from 2001 to 2011, indicating that the land use and land cover of the watershed remained essentially the same. Only subbasin 3 underwent measureable change in three land use categories: deciduous forest $(0.23 \%)$, grassland $(0.77 \%)$, and cropland (0.31\%). All other subbasins had no or minimal $(0.02 \%$ to $0.17 \%)$ land cover changes.

Hydrological Calibration and Verification. The HSPF model of the upper Cherry Creek watershed was calibrated and verified for stream flow. The model results performed for the time period from September of 1976 to September of 1982 illustrate the quality of the hydrological calibration by comparing simulated daily stream flow to measured daily data at Hallowell (USGS station 07184300) (figure 4). The model adequately captures low flows and peaks of stream events.

Moriasi et al. (2007) recommended that three statistical fit indicators - ratio of the root-mean-squared-error to the standard deviation of measured data (RSR), PBIAS, and Nash-Sutcliffe efficiency (NS)-should meet the following requirements: RSR $<0.70,-25 \%<$ PBIAS $<25 \%$, and NS $>$ 0.5 , when stream flow is simulated with a monthly time-step. They also recommended that these ranges need to be modified appropriately for shorter simulation time-steps. For example, for daily time-steps the requirements are less stringent because model simulations are not as accurate for shorter time-steps than for longer time-steps. The following ranges for indicators of fit at a daily simulation level were suggested: $R^{2}>0.5$ and NS $>0.395$. In this research, all hydrological and water quality simulations were at a daily time-step, so the following ranges for indica- 
tors of fit were adopted: RSR $<0.75,-30 \%$ $<$ PBIAS $<30 \%, R^{2}>0.6$, and NS $>0.5$. All of the statistical indicators of fit for the stream flow model output were well within these requirements: $\mathrm{RSR}=0.60$, PBIAS $=$ $-0.50 \%, R^{2}=0.64$, and NS $=0.64$ (figure 4 ).

To verify that the statistical quality of the calibration results was replicated with an independent data set, model-estimated daily stream flow was compared to measured flows at the upstream West Mineral USGS station (07184220) (figure 5). Six time periods of continuous daily measured data were available at this location. For brevity, model verification results from only three of the time period comparisons are presented: best, intermediate, and worst statistical fit. Results from both the hydrological calibration (September 2, 1976, to September 30, 1982) and the verification process (April 24, 1977, to September 30, 1977; October 18, 1977, to June 23, 1978; and April 11, 1979, to May 16, 1979) are summarized in table 5.

Three of the four statistical indicators demonstrate that the fit of simulated stream flow to measured stream flow is good based on our requirements (table 5). The comparison for the most extended simulation time period (September 2, 1976, to September 30, 1982) that covers all the geographical area of the upper Cherry Creek watershed had the second best combination of statistical indicators of fit. The second longest comparison time period (April 24, 1977, to September $30,1977)$ in the verification step has the best statistical indicators of fit. For the shortest comparison time period (April 11, 1979, to May 16, 1979), during which an extreme flash-flood event occurred, the event is very well replicated by the model output with the highest $R^{2}$ and NS coefficients (closer to the optimal value of 1 in both cases), and the lowest RSR coefficient (closer to the optimal value of 0 ). The statistical indicators for the comparison period October 18, 1977, to June 23, 1978, are moderate: RSR and PBIAS are well within the ranges specified as good, and $R^{2}$ and NS are of moderate quality. During this period of time there were several flood events and subsequent stream flow recession limbs that are captured appropriately by the model. Nevertheless, from January 15 to February 28, 1978 (figure 5b), the model simulates two flood events that are not consistent with observed stream flow data. The weather station at Columbus (figure 2) recorded precipitation events consistent

\section{Figure 3}

Land use and land cover in the Cherry Creek watershed (NLCD 2001 data set).

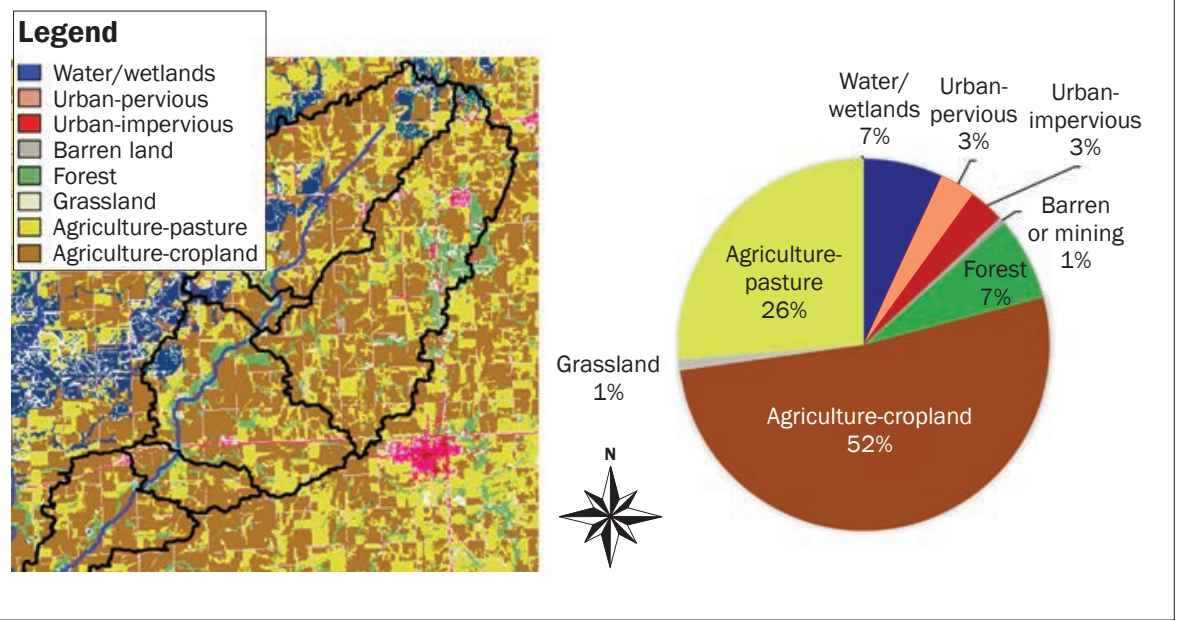

Table 4

Change in land use/land cover in the Cherry Creek watershed.

\begin{tabular}{llrrrrr}
\hline & \multicolumn{7}{l}{ Change/no-change in subbasin (\%) } \\
\cline { 2 - 7 } Land use/land cover & \multicolumn{1}{c}{} & \multicolumn{1}{l}{$\mathbf{2}$} & $\mathbf{3}$ & $\mathbf{5}$ & $\mathbf{6}$ & $\mathbf{7}$ \\
\hline No change & 99.80 & 99.69 & 98.69 & 99.91 & 99.95 & 100 \\
Open water & 0.00 & 0.02 & 0.00 & 0.01 & 0.03 & 0 \\
Urban & 0.02 & 0.00 & 0.00 & 0.03 & 0.02 & 0 \\
Barren land & 0.00 & 0.17 & 0.00 & 0.00 & 0.00 & 0 \\
Deciduous forest & 0.18 & 0.00 & 0.23 & 0.00 & 0.00 & 0 \\
Grassland & 0.00 & 0.04 & 0.77 & 0.00 & 0.00 & 0 \\
Agriculture-pasture & 0.00 & 0.07 & 0.00 & 0.05 & 0.00 & 0 \\
Agriculture-crops & 0.00 & 0.00 & 0.31 & 0.00 & 0.00 & 0 \\
\end{tabular}

with the simulated stream flow peaks. This means that the precipitation events were not homogeneous across the entire region. The rain events that occurred within the Cherry Creek watershed were of much lower magnitude than those registered at Columbus and therefore did not result in flood events in Cherry Creek. However, during the majority of the simulation, the statistical indicators were good. Therefore, the model was considered calibrated and verified for stream flow.

\section{Water Quality Calibration and} Verification. The calibration of the water quality portion of the modeling effort was performed by comparing simulated and measured concentration values for $\mathrm{NO}_{3}^{-}-\mathrm{N}$, TAM, and TP at the Hallowell USGS station (07184300). Verification of the model output was performed comparing $\mathrm{NO}_{3}^{-}-\mathrm{N}$, TAM, and TP simulated output to measured data at the West Mineral USGS station (07184220). Figure 6 summarizes the statistical and graphical comparison.
Due to the limited availability of measured data and also because several data values were reported as below minimum quantifiable level, statistical fit indicators were calculated only for $\mathrm{NO}_{3}^{-}-\mathrm{N}$ and TAM (figure 6). For simulation of water quality, Moriasi et al. (2007) reported wide ranges of statistical fit. For example, while NS values for hydrology were set to $>0.395$ as an acceptable level, for $\mathrm{NO}_{3}^{-}-\mathrm{N}$ ranges were calculated from -0.08 to 0.26 . This variability in conditions for water quality parameters permits more lenient fitness coefficients. Our results find $R^{2}$ and NS for $\mathrm{NO}_{3}{ }^{-} \mathrm{N}$ were good at both locations. However, simulated results for TAM were not as good at either location. RSR was out of range for all simulated results, while PBIAS showed much greater variability, with only one simulated level out of range $\left(\mathrm{NO}_{3}^{-}-\mathrm{N}\right.$ at West Mineral). Overall, the statistical fit indicators achieved for $\mathrm{NO}_{3}{ }^{-} \mathrm{N}$ and TAM in our model of Cherry Creek watershed (table 6) were of moderate 


\section{Figure 4}

Hydrological calibration results for the Cherry Creek watershed Hydrological Simulation Program Fortran model.

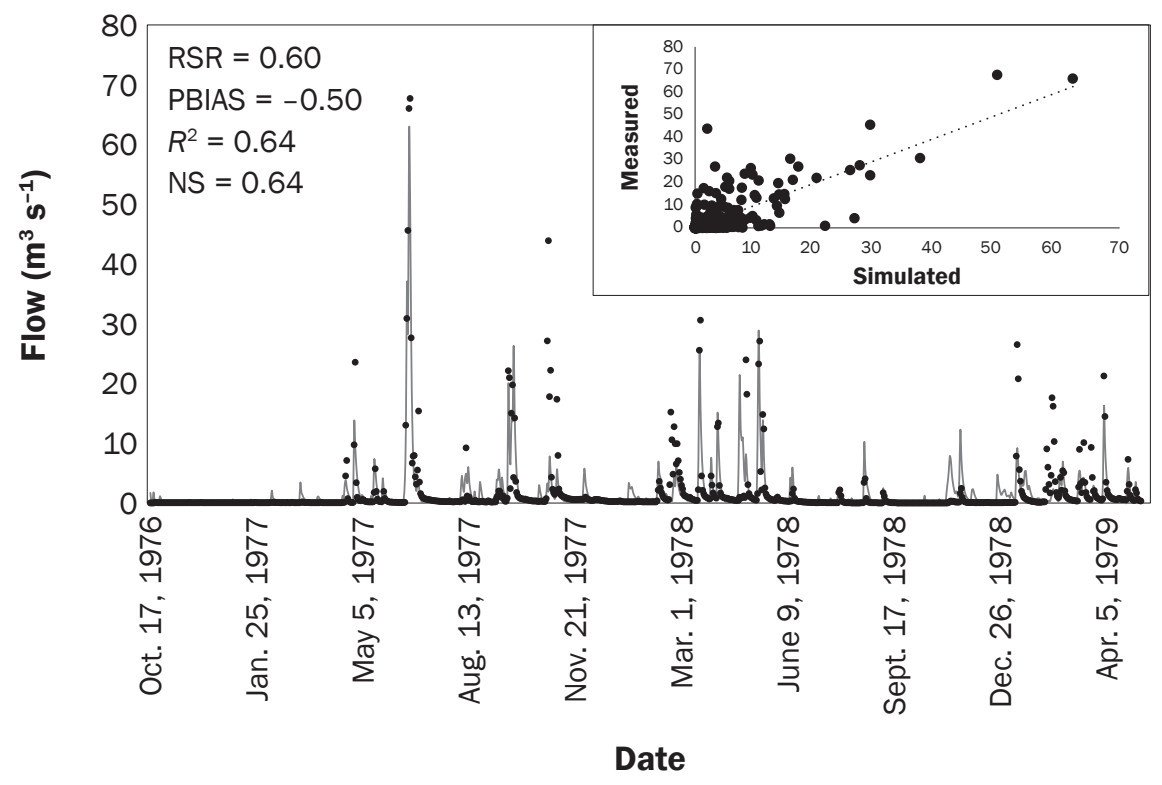

\section{Legend}

- Simulated - Measured

quality, but acceptable for daily simulations of these nutrient components.

For TP (table 6 and figure 7) the statistical indicators of fit show weaker performance of the model to measured data. All of the statistical measures were well outside of the optimal ranges, with the exception of PBIAS, which was near $12 \%$ at both locations. It is interesting to see that at least half of the reported measured data are lower than $0.05 \mathrm{mg} \mathrm{P} \mathrm{L}^{-1}$ at both locations. The reported data from USGS for both stations did not include minimum quantification limits. In fact, several of the reported data were $0.0 \mathrm{mg} \mathrm{L}^{-1}$, which is inconsistent with current reporting and laboratory procedure. The USEPA (Wayman et al. 1999) uses two important concepts when setting detection limits of water quality samples: the minimum concentration of a substance that can be measured and reported with 99\% confidence that the true value is greater than zero (method detection limit [MDL]), and the lowest level that can be reliably achieved within the specified limits of precision and accuracy during routine laboratory operating conditions (practical quantitation level [PQL]). For $\mathrm{P}$, common values for $\mathrm{MDL}$ and PQL are $0.01 \mathrm{mg} \mathrm{L}^{-1}$ and $0.05 \mathrm{mg} \mathrm{L}^{-1}$ as $\mathrm{P}$ (CDPH 2015). Although concentra- tion values between the MDL and PQL are uncertain, they should be reported because those values give indications or trends of water quality constituent concentrations (USEPA 2006). These considerations led the calibration and subsequent verification processes to be focused on replicating trends and range of concentrations rather than fitting simulation results to measured values that may have a high degree of uncertainty. In this context, the model simulations are consistent with the order of magnitude and trends of the measured $\mathrm{P}$ concentrations.

An additional verification with a completely independent data set was performed for $\mathrm{NO}_{3}^{-}-\mathrm{N}$, TAM, and $\mathrm{PO}_{4}^{3-}-\mathrm{P}$ using data collected near Faulkner, Kansas, downstream of USGS station 07184300 (figure 8). Because several concentration values were flagged as below the MQL $\left(0.1 \mathrm{mg} \mathrm{L}^{-1}\right.$ for $\mathrm{NO}_{3}^{-}-\mathrm{N}$ and TAM, and $0.25 \mathrm{mg} \mathrm{L}^{-1}$ for $\left.\mathrm{PO}_{4}^{3-}-\mathrm{P}\right)$, calculation of statistical indicators of fit was not possible. As with TP, this additional verification focused on replicating trends and range of concentration values.

Water Quality Simulation, Probability of Exceedance, and Water Quality Indicators. The hydrological and water quality model for Cherry Creek correctly simulated water transport, and simulated $\mathrm{NO}_{3}^{-}-\mathrm{N}$, TAM, and $\mathrm{PO}_{4}^{3-}-\mathrm{P}$ transport within acceptable limits. The model was next used to explore potential sources or patterns of pollutants by simulating continuous daily concentrations of $\mathrm{NO}_{3}^{-}-\mathrm{N}, \mathrm{TAM}$, and $\mathrm{PO}_{4}^{3-}-\mathrm{P}$ for a 32-year period of time from 1976 through 2008. Figure 9 shows simulated time-series for $\mathrm{NO}_{3}^{-}-\mathrm{N}$, TAM, and $\mathrm{PO}_{4}^{3-}-\mathrm{P}$. Numerical values of statistical descriptors of the simulated values are included for each parameter over the 32-year period. In general, concentrations follow a seasonal pattern: low concentrations are observed early in the calendar year and high concentrations are simulated during or at the end of summer. This seasonal trend is consistent with the extensive use of fertilizer applications in the spring with planting, followed by additional applications later, and potentially indicates that the nonpoint source of nutrient concentrations is due to agricultural activity. For $\mathrm{NO}_{3}^{-}-\mathrm{N}$, the model estimates a maximum concentration of $10 \mathrm{mg} \mathrm{L}^{-1}$ with a median of $0.011 \mathrm{mg} \mathrm{L}^{-1}$. Twenty-five percent of the simulated concentration values are lower than $0.005 \mathrm{mg} \mathrm{L}^{-1}$ while $75 \%$ of the concentrations are below 0.072. Overall, $\mathrm{NO}_{3}^{-}-\mathrm{N}$ concentrations are low in Cherry Creek. Total ammonia concentrations calculated by the model are lower than $\mathrm{NO}_{3}^{-}-\mathrm{N}$ concentrations. The maximum concentration for TAM is $2.6 \mathrm{mg} \mathrm{L}^{-1}$, and $75 \%$ of the simulated concentrations are lower than $0.41 \mathrm{mg}$ $\mathrm{L}^{-1}$. The interquartile range (IQR) of TAM simulations is $0.28 \mathrm{mg} \mathrm{L}^{-1}$ while the IQR for $\mathrm{NO}_{3}^{-}-\mathrm{N}$ is 0.40 . Since the maximum concentration for TAM is much lower than for $\mathrm{NO}_{3}^{-}-\mathrm{N}$, extreme concentration events for $\mathrm{NO}_{3}^{-}-\mathrm{N}$ (outliers) are more frequent and follow a seasonal pattern (figure 9). This pattern is also seen for $\mathrm{PO}_{4}^{3-}-\mathrm{P}$. The maximum simulated concentration for $\mathrm{PO}_{4}^{3-}-\mathrm{P}$ is $1.62 \mathrm{mg} \mathrm{L}^{-1}$, with an IQR equal to $0.067 \mathrm{mg}$ $\mathrm{L}^{-1}$. Therefore, events with extreme $\mathrm{PO}_{4}^{3-}-\mathrm{P}$ concentrations are also more frequent for this water quality constituent. Seventy-five percent of the $\mathrm{PO}_{4}^{3-}-\mathrm{P}$ concentration values calculated by the model are lower than 0.072. The use of manure (from poultry or cattle grazing) as fertilizer could be the source for the excess nutrients in general and $\mathrm{P}$ in particular.

With long-term continuous daily simulations of $\mathrm{NO}_{3}^{-}-\mathrm{N}$, TAM, and $\mathrm{PO}_{4}^{3-}-\mathrm{P}$ concentrations, we can now calculate the percentage probabilities that the water quality constituents would equal or exceed 


\section{Figure 5}

Hydrological verification results for three of the six time periods: (a) best fit, (b) worst fit, and (c) intermediate fit.

(a)

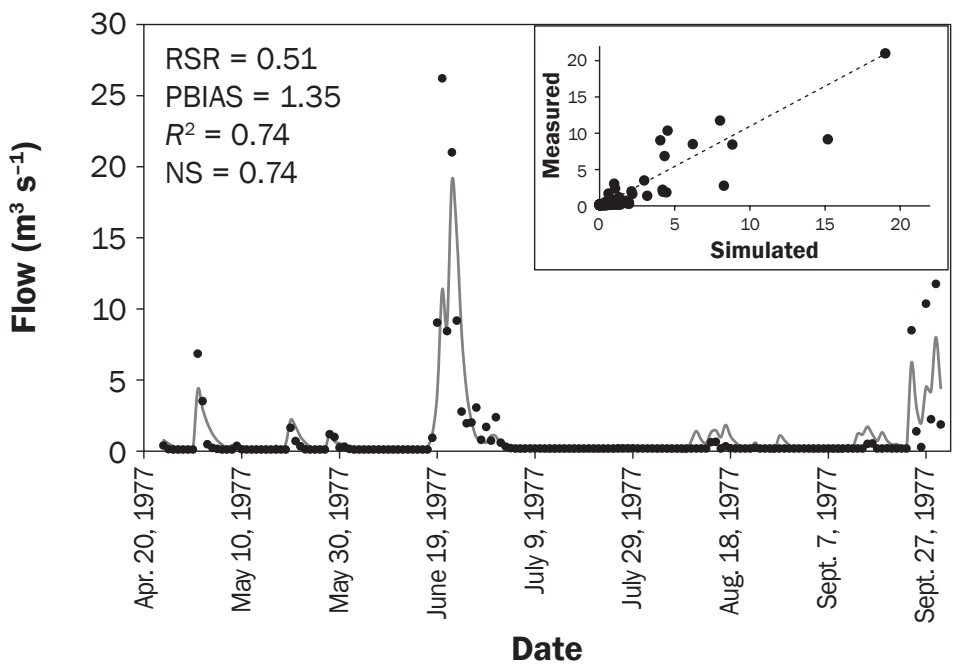

(b)

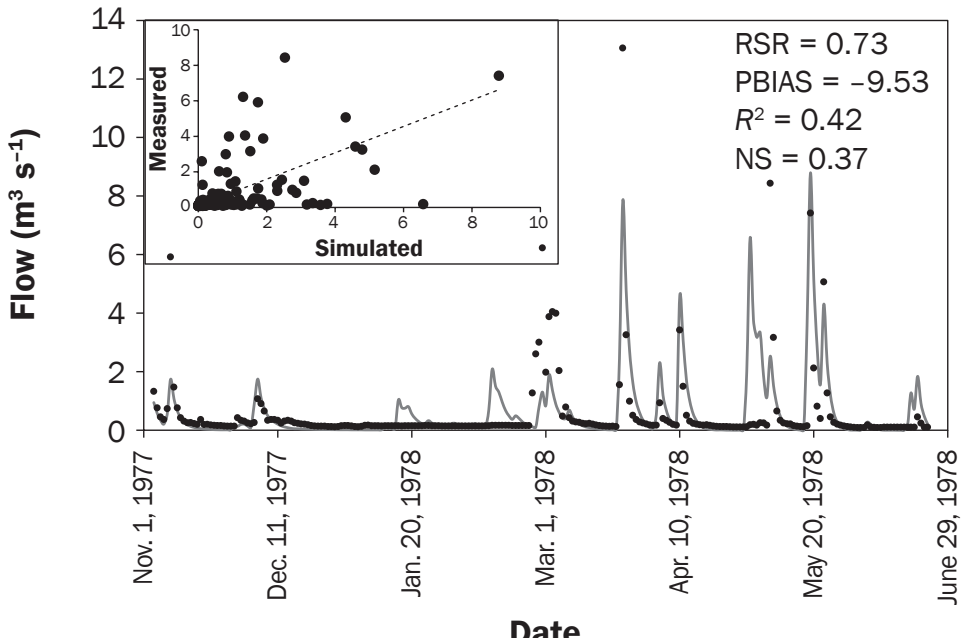

(c)

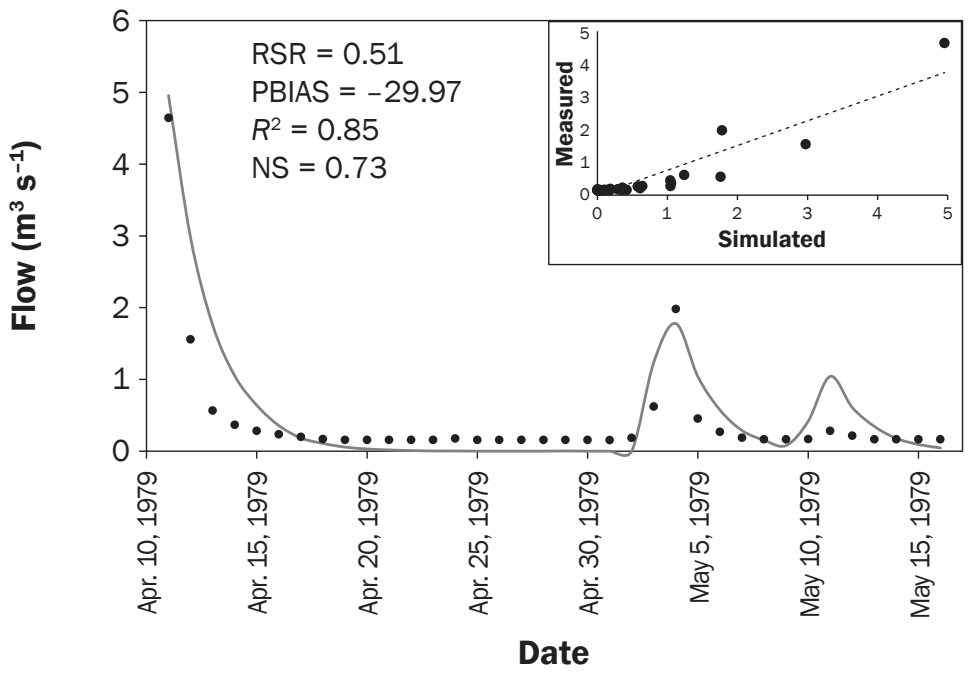

Legend

- Simulated

- Measured concentration values that are critical either for human health or for aquatic ecosystems (table 7). Ninety-nine percent confidence bands were also calculated to account for the uncertainty inherent in the long-term water quality simulations. Upper confidence bands were used to establish probabilities of exceedance because upper bounds are more appropriate when water quality criteria are set up as maximum concentrations. The maximum simulated concentration of $\mathrm{NO}_{3}^{-}-\mathrm{N}$ was $10 \mathrm{mg} \mathrm{L}^{-1}$. The USEPA established $10 \mathrm{mg} \mathrm{L}^{-1}$ as the maximum $\mathrm{NO}_{3}^{-}-\mathrm{N}$ level allowed in drinking water (USEPA 2016; Reilly et al. 1999). The probability of exceedance of this concentration is minimal in Cherry Creek (lower than 0.01\%; figure 10). The established water quality criteria for aquatic ecosystem health sets $\mathrm{NO}_{3}^{-} \mathrm{N}$ levels at a concentration of $0.98 \mathrm{mg} \mathrm{L}^{-1}$ or lower. Higher levels of $\mathrm{NO}_{3}^{-}-\mathrm{N}$ promote the growth of eutrophic species (table 7). Based on the simulations performed here, the probability that $\mathrm{NO}_{3}^{-}-\mathrm{N}$ levels will exceed this lower limit in Cherry Creek is 9\%. For TAM, $1 \mathrm{mg} \mathrm{L}^{-1}$ is identified in the literature as a threshold value of impairment for aquatic life (table 7). The exceedance probability for this concentration is $3 \%$, while the probability corresponding to a concentration of 1.24 , identified by KDHE (2015) as a toxicity threshold for surface waters where fish are present, is $1.6 \%$. For $\mathrm{PO}_{4}^{3-}-\mathrm{P}$, the maximum acceptable concentration that would avoid algal blooms and subsequent eutrophication is $0.05 \mathrm{mg} \mathrm{L}^{-1}$. The probability of exceedance of a $\mathrm{PO}_{4}^{3-}-\mathrm{P}$ concentration of 0.05 in Cherry Creek is $30.4 \%$.

Water quality assessed for individual water quality constituents may obscure compounding effects of multiple pollutants in stream water quality. The WQI numerical value takes into consideration the compounding effect of $\mathrm{NO}_{3}^{-}-\mathrm{N}$, TAM, and $\mathrm{PO}_{4}^{3-}-\mathrm{P}$ estimations and their corresponding water quality criteria to produce a single water quality index attributable to a stream (Terrado et al. 2010). The WQI was calculated for each subbasin within the Cherry Creek watershed and for the entire watershed over the 32-year period from 1976 until 2008. The deviation of the WQI for each subbasin relative to the total watershed is presented in figure 11. The data not only demonstrate the temporal variability over the 32-year time span, but also the spatial variability in water quality within the individual subbasins in the Cherry Creek 
Table 5

Results of the hydrological calibration and verification of the Cherry Creek watershed Hydrological Simulation Program Fortran (HSPF) model.

\begin{tabular}{|c|c|c|c|c|}
\hline Comparison period & RSR $<0.75$ & $\begin{array}{l}-30 \%< \\
\text { PBIAS }<30 \%\end{array}$ & $R^{2}>0.6$ & NS $>0.5$ \\
\hline Sept. 2, 1976, to Sept. 30, 1982* & 0.60 & -0.50 & 0.64 & 0.64 \\
\hline Apr. 24,1977 , to Sept. 30, $1977 \dagger$ & 0.51 & 1.35 & 0.74 & 0.74 \\
\hline Oct. 18,1977 , to June 23,1978 * & 0.73 & -9.53 & 0.42 & 0.37 \\
\hline Apr. 11,1979 , to May $16,1979 \dagger$ & 0.51 & -29.97 & 0.85 & 0.73 \\
\hline \multicolumn{5}{|c|}{$\begin{array}{l}\text { Notes: } \mathrm{RSR}=\text { root-mean-squared-error to standard deviation ratio. } \mathrm{PBIAS}=\text { percentage bias. } R^{2}= \\
\text { coefficient of determination. NS = Nash-Sutcliffe efficiency. }\end{array}$} \\
\hline \multicolumn{5}{|c|}{ *Calibration, Hallowell station. } \\
\hline †Verification, West Mineral station & & & & \\
\hline
\end{tabular}

watershed. In general, subbasin 1 has a lower mean than the total watershed average WQI, indicating the water in this subbasin is of higher quality. From October of 1987 to October of 1995 , the relative deviation is negative at various points, indicating that water quality is better than the averaged WQI. Conversely, the WQI of subbasin 6 is consistently the highest, indicating poorer water quality in this subbasin. As pollutants would be expected to concentrate further downstream in the watershed, it is not surprising that the water quality of subbasin 1 is better than that in subbasin 6 . However, it would be expected that the final subbasin, 7 , would have the greatest impairment if this was the only consideration contributing to pollutant load. Interestingly, results from a correlation analysis show no apparent correlation between the amount of precipitation and the WQI in the watershed.

As shown in figure 2, the shape of subbasin 6 divides the subwatershed so that the length of the stream it contains is shorter, relative to the transect width of the subwatershed, than in subbasins 7, 5, and 1 . Therefore, runoff does not as effectively reach the stream due to large times of concentration in subbasin

\section{Figure 6}

Water quality calibration at (a and c) Hallowell station and verification at ( $b$ and d) West Mineral station for (a and b) nitrate-nitrogen ( $\mathrm{NO}_{3}^{-}-\mathrm{N}$ ) and $(\mathrm{c}$ and d) total ammonia (TAM). Statistical parameters of fitness were calculated according to equations detailed in table 3.

(a)

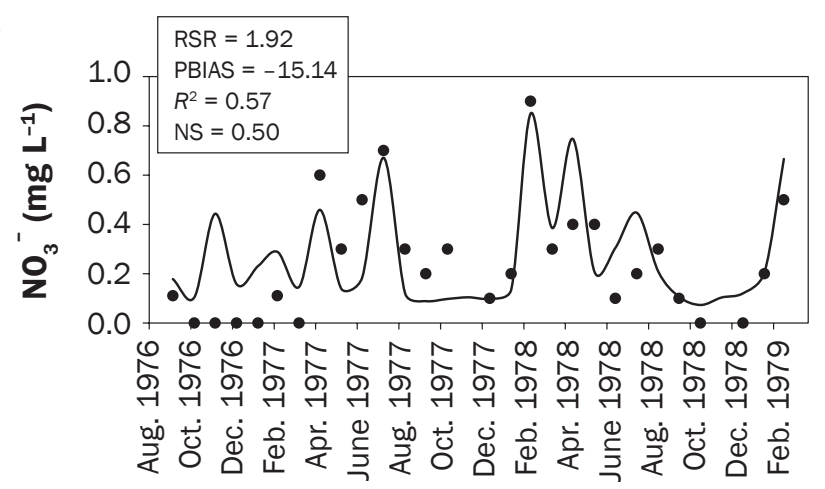

Date

(c)

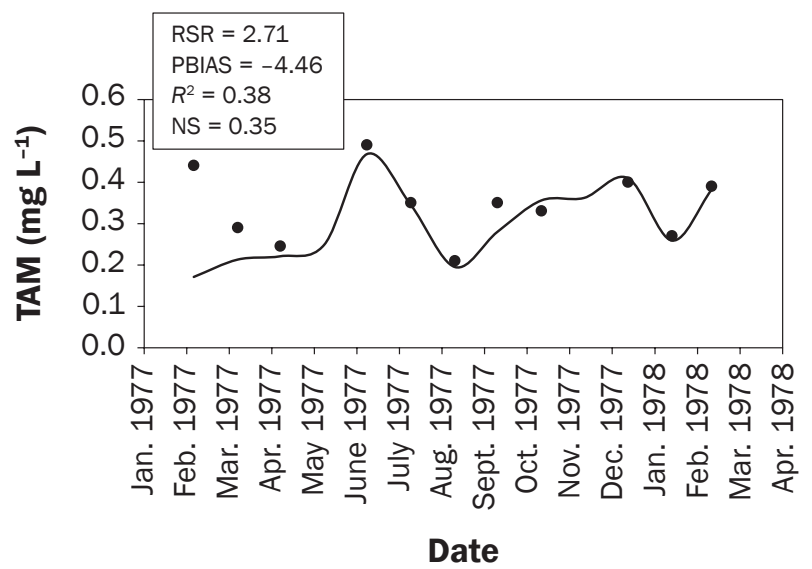

(b)

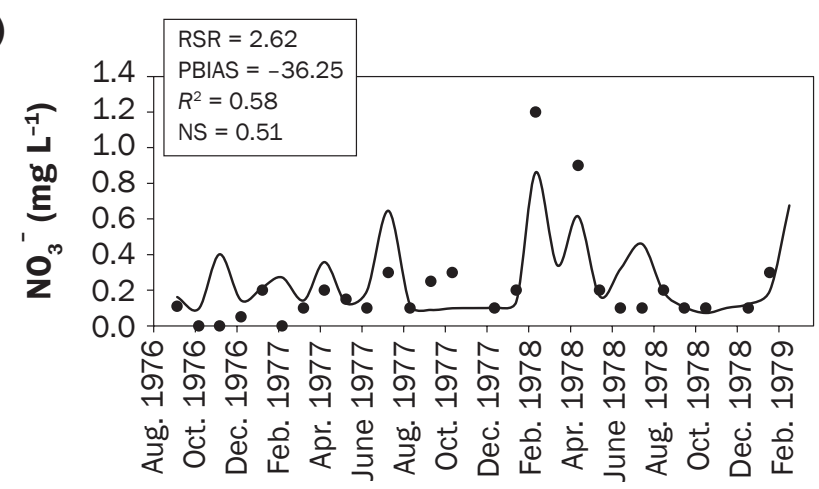

Date

(d)

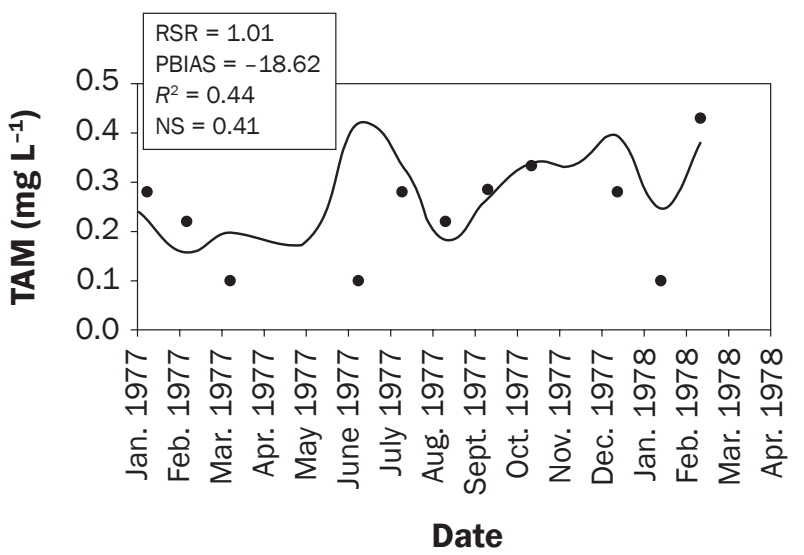

\section{Legend}


6 . The time of concentration of a watershed measures the response of a watershed to a rain event and is defined as the time needed for water to flow from the most remote point in a watershed to the watershed outlet. Since the stream catchment does not collect water efficiently, dilution effects are limited. Also, water entering the stream from the vadose zone (interflow) is also limited by the length of the stream segment and the distances travelled laterally in the subsurface to reach the stream. Subbasin 6 contains approximately 83\% of lands dedicated to agriculture (crops and pasture). Therefore, the water that washes off the nearby area and reaches the stream may contain relatively high nutrient concentrations. These waters, although small in volume, rather than diluting the receiving waters instead further enrich its nutrient concentrations.

To further compare WQI values between subbasins, nonparametric statistical indicators were computed for WQI values of each subbasin (minimum, first quartile, median, and third quartile; figure 12). The first quartile indicates the amount of time that $75 \%$ of the readings are above a given value. For the Cherry Creek watershed, the first quartile of WQI values for all subbasins is above 74.2, indicating that water quality is at least fair (usually protected but occasionally threatened or impaired). The median value shows that WQI is higher than 93.3 for $50 \%$ of the time (i.e., water quality has only a minor degree of threat or impairment). Moreover, the upper quartile WQI shows that WQI is above 96.7 for $25 \%$ of the time. Hence, water quality is excellent in all subbasins, with a virtual absence of threat or impairment. Nevertheless, a slight degrading trend of the water quality in the Cherry Creek watershed is observed from subbasin 1 to subbasin 7 . For all subbasins, water quality is poor (WQI $<44$ ) less than $1 \%$ of the time and water quality is marginal (WQI < 64) less than $6 \%$ of the time.

\section{Summary and Conclusions}

The Cherry Creek watershed, located in southeast Kansas, is a contributor of water to the Grand Lake watershed via the Neosho River. The watershed drains approximately $882.2 \mathrm{~km}^{2}(218,000 \mathrm{ac})$ of land, of which at least $78 \%$ are agricultural lands. Several studies have identified the watershed as a targeted area for agricultural BMPs to meet sediment and nutrient load reductions, and for TMDL design oriented toward reducing

\section{Table 6}

Statistical fitness results of the water quality calibration and verification process.

\begin{tabular}{lllll}
\hline Comparison period & RSR $<\mathbf{0 . 7 5}$ & $\begin{array}{l}-\mathbf{3 0} \%< \\
\text { PBIAS }<\mathbf{3 0} \%\end{array}$ & $\boldsymbol{R}^{\mathbf{2}}>\mathbf{0 . 6}$ & NS $>\mathbf{0 . 5}$ \\
\hline $\mathrm{NO}_{3}{ }^{-}$-N: Feb. of 1976, to Mar. of 1979* & 1.92 & -15.14 & 0.57 & 0.50 \\
TAM: Jan. of 1977, to Mar. of 1978* & 2.71 & -4.46 & 0.38 & 0.35 \\
$\mathrm{NO}_{3}{ }^{-}$-N: Feb. of 1976, to Mar. of 1979† & 2.62 & -36.25 & 0.58 & 0.51 \\
TAM: Jan. of 1977, to Mar. of 1978-3/78† & 1.01 & -18.62 & 0.44 & 0.41 \\
TP: Jan. of 1977, to Mar. of 1978* & 2.99 & 12.00 & 0.11 & 0.01 \\
TP: Jan. of 1977, to Mar. of 1978† & 2.39 & 12.35 & 0.16 & 0.05 \\
\hline
\end{tabular}

Notes: RSR = root-mean-squared-error to standard deviation ratio. $\mathrm{PBIAS}=$ percentage bias. $R^{2}=$ coefficient of determination. $\mathrm{NS}=$ Nash-Sutcliffe efficiency. $\mathrm{NO}_{3}{ }^{-}-\mathrm{N}=$ nitrate-nitrogen. TAM $=$ total ammonia. TP = total phosphorus.

*Calibration, Hallowell station.

†Verification, West Mineral station.

nutrient and sediment loads. This paper presents a water quality assessment in the Cherry Creek watershed by means of a hydrological and water quality model, developed using the HSPF code. The model was calibrated and verified with measured data reported by USGS and the KDHE.The development of the model was performed in two phases: (1) modeling of the upper Cherry Creek watershed (catchment exit at Hallowell), and (2) modeling of the entire Cherry Creek watershed (catchment exit at Faulkner). The model was designed to simulate water quality in terms of $\mathrm{NO}_{3}^{-}-\mathrm{N}$, TAM, TP, and $\mathrm{PO}_{4}^{3-}-\mathrm{P}$ concentrations.

Hydrological calibration and verification and subsequent extrapolation of hydrological parameters from the upper Cherry Creek model to the entire Cherry Creek watershed model were successful given the relatively small number of water samples of nutrient analysis used to build the model. Although water quality calibration and verification were hindered by measured nutrient concentration values that were lower than the MQL, by orienting the calibration and verification toward replicating trends and ranges of measured nutrient concentrations, a model was produced that was able to simulate comparable measured concentration values recorded at an independent water quality station downstream of the upper Cherry Creek model.

Our results show that concentration values of nitrogenous contaminants $\left(\mathrm{NO}_{3}^{-}-\mathrm{N}\right.$ and TAM) are generally low for this agricultural watershed: $75 \%$ of the $\mathrm{NO}_{3}^{-}-\mathrm{N}$ and TAM concentrations are lower than $0.41 \mathrm{mg} \mathrm{L}^{-1}$. However, peak values of $\mathrm{NO}_{3}^{-}-\mathrm{N}$ can reach concentration values above $5 \mathrm{mg} \mathrm{L}^{-1}$ up to $10 \mathrm{mg} \mathrm{L}^{-1}$, usually in mid-year (summer or early autumn). This indicates that $\mathrm{NO}_{3}^{-}-\mathrm{N}$ is related to crop production activities and/ or low flow conditions in the river. A similar pattern is observed for TAM. The likelihood that the $\mathrm{NO}_{3}^{-}-\mathrm{N}$ and TAM concentrations could become toxic for aquatic communities is low: $9 \%$ and $3 \%$, respectively.

Although low concentrations are also observed for $\mathrm{PO}_{4}^{3-}-\mathrm{P}$, if the USEPA criteria for $\mathrm{PO}_{4}^{3-}-\mathrm{P}$ in surface waters (maximum 0.05 $\mathrm{mg} \mathrm{L}^{-1}$ ) are taken into account, even these low concentrations may promote eutrophication. According to our simulation results, concentrations of $\mathrm{PO}_{4}^{3-}-\mathrm{P}$ in Cherry Creek have a probability of exceeding that maximal level $30.4 \%$ of the time. With a maximum simulated concentration of $1.62 \mathrm{mg} \mathrm{L}^{-1}$ and an IQR of only $0.067 \mathrm{mg} \mathrm{L}^{-1}$, indicating the existence of frequent extreme concentration events, future research is needed for assessing the $\mathrm{PO}_{4}^{3-}-\mathrm{P}$ activity in Cherry Creek. Extensive use of animal manure, either imported from neighboring confinement operations (primarily poultry) or from cattle grazing on pasture, would contribute excess levels of nutrients, especially P (Tomlinson et al. 2014, 2015). This may account for the elevated levels of $\mathrm{PO}_{4}^{3-}-\mathrm{P}$ observed in the watershed, and indicate the need to target improved methods of animal manure management within the watershed to improve water quality.

The results indicate the suitability of the HSPF model for tracking and predicting nutrient flows in agricultural watersheds. The methodology for assessing overall water quality is also shown to be appropriate. The WQI calculations showed that water quality in upstream subbasins is better than in downstream subbasins, although agricultural activity was present in all subbasins. A slight degrading trend of water quality within the Cherry Creek watershed (from subbasin 1 to subbasin 7) was identified. No appar- 


\section{Figure 7}

Water quality calibration and verification for total phosphorus (TP) for (a) Hallowell and (b) West Mineral.

(a)

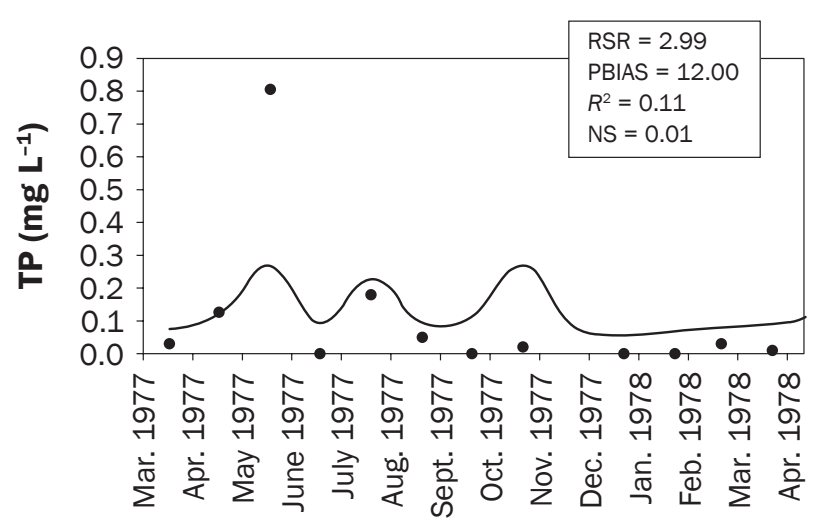

Date (b)

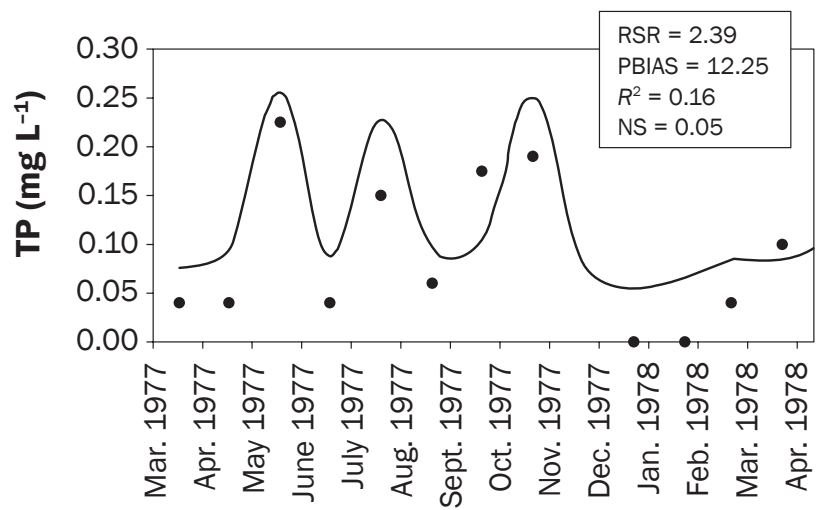

\section{Figure 8}

Water quality verification for (a) nitrate $\left(\mathrm{NO}_{3}^{-}\right)$, (b) total ammonia (TAM), and (c) orthophosphate $\left(\mathrm{PO}_{4}{ }^{3-}\right)$ for simulated and measured values at Faulkner, Kansas. The charts show the minimum quantifiable limit (MQL; concentrations below which analytical methods cannot operate with precision) for each of the water quality constituents.

(a)

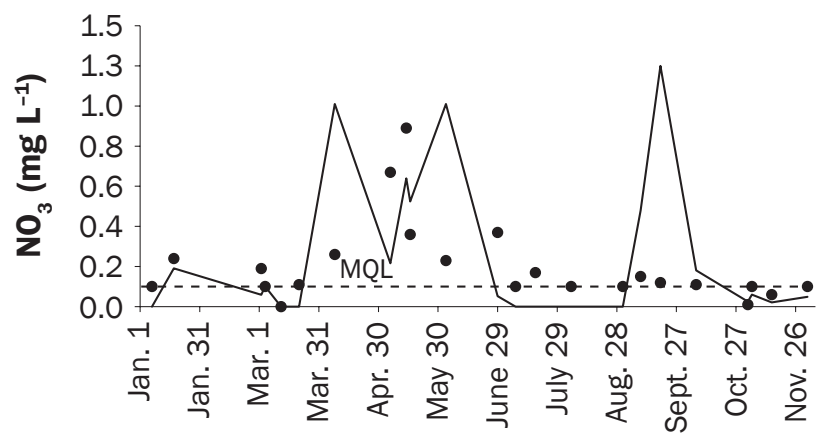

Date

(c)

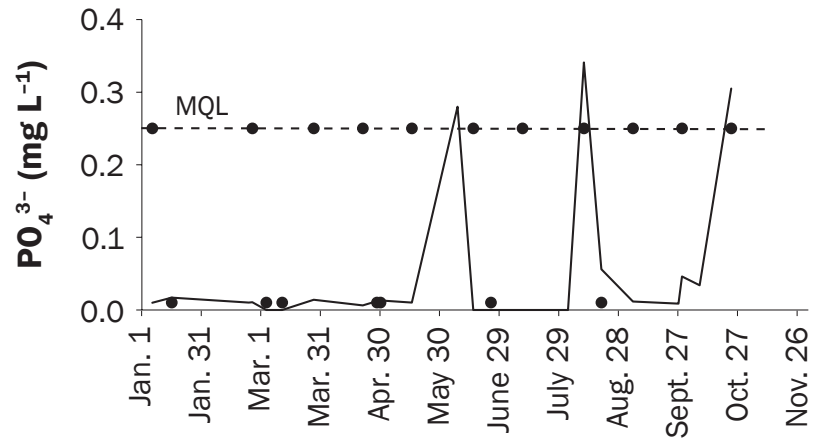

(b)

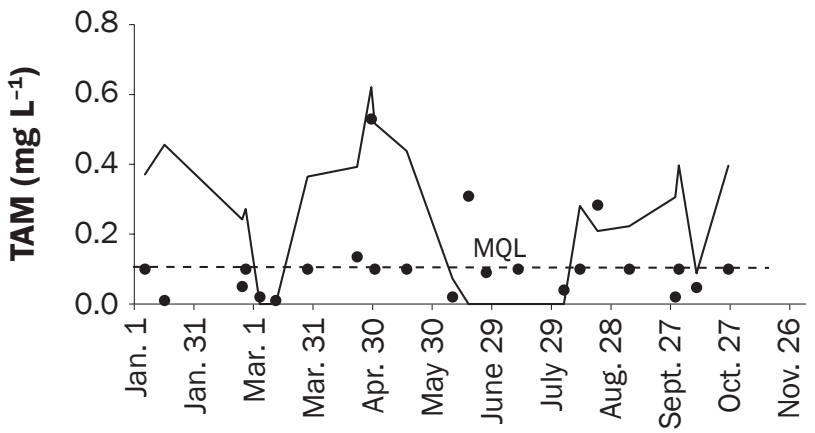

Date

\section{Legend}

- Simulated - Measured

\section{Date}


Figure 9

Water quality simulation for October 20, 1976, to December 20, 2008. (a) Daily nitrate-nitrogen $\left(\mathrm{NO}_{3}^{-}-\mathrm{N}\right),(b)$ total ammonia (TAM), and (c) orthophosphate $\left(\mathrm{PO}_{4}{ }^{3-}-\mathrm{P}\right)$ concentrations.

(a)

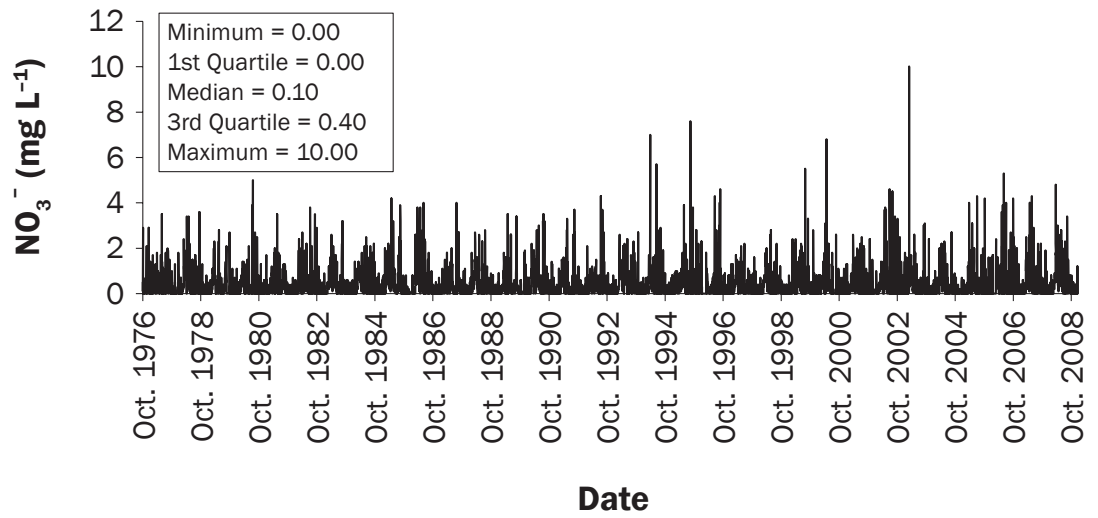

(b)

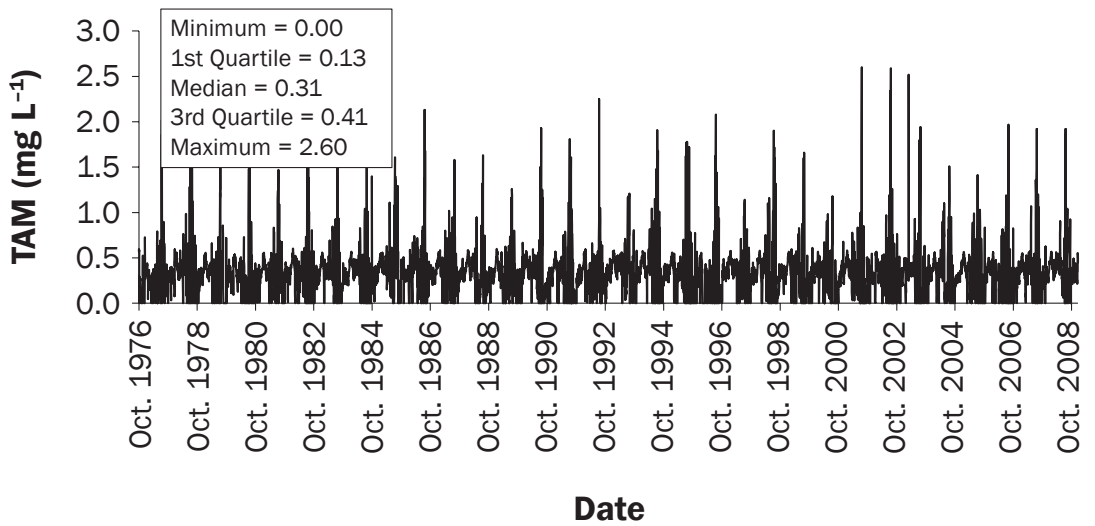

(c)

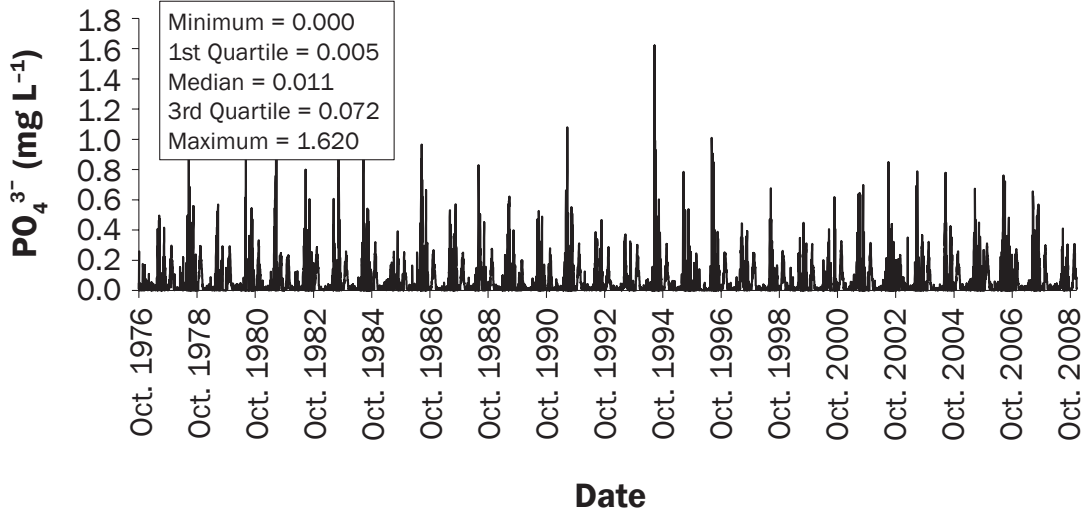

ent correlation between wet and dry season conditions with cumulative WQI peaks and minimums were present. The low levels of nitrogenous contaminants and high values of the WQI (meaning that waters have fair to excellent quality most of the time) are surprising for an agricultural watershed, indicating that other factors are contributing to the reported low measured levels of DO in the stream. Low DO concentrations have been mainly attributed to incoming BOD from waste water stabilization lagoons located in subbasins 1 and 2, a livestock waste management system located in subbasin 7 , and sediment reaching the streams from nonpoint sources (cropland and pasture land) (KDHE 2017a). However, naturally occurring conditions may also play a role; low flow and regular interaction with gravel bars could be a contributing factor to low DO events (KDHE 2017b). Moreover, the Cherry Creek watershed is not contributing substantially to the contamination of rivers and lakes further downstream. An important consideration is the limited water quality data set available from the region. Agricultural practices and land use changes may have changed nutrient concentrations in the water of the region. The limited data set points to the critical need for more frequent sampling intervals and additional water quality analysis.

The current methodology will be useful in assessing nutrient conditions in other streams with the MNW. The model will also be useful for exploring the impacts of agricultural activities on water quality and developing conservation plans to address impaired water systems of the region (Tomer et al. 2013; OWRB 2001).

\section{Acknowledgements}

This research was funded by a grant from CONICYT REDES 140045. This manuscript is contribution number 16-274-J from the Kansas Agricultural Experiment Station. This work was supported in part by the USDA National Institute of Food and Agriculture, Hatch project 1003478.

\section{References}

Alarcon, V.J., and C.G. O'Hara. 2010. Scale-dependency and sensitivity of hydrological estimations to land use and topography for a coastal watershed in Mississippi. Lecture Notes in Computer Science 6016:491-500.

Alarcon,V.J., and G.F. Sassenrath. 2015. Sensitivity of nutrient estimations to sediment wash-off using a hydrological model of Cherry Creek Watershed, Kansas. Lecture Notes in Computer Science 9157:457-467.

Alarcon, V.J., and G.F. Sassenrath. 2016. Modeling and simulating nutrient management practices for the Mobile River Watershed. Lecture Notes in Computer Science 9788:33-43.

Bernal, E. 2014. Chapter 3: Limit of Detection and Limit of Quantification Determination in Gas Chromatography. In Advances in Gas Chromatography. London: In Tech. http://cdn.intechopen.com/pdfs-wm/46058.pdf.

Bicknell, B.R., J.C. Imhoff, J.L. Kittle, Jr., A.S. Donigian, Jr., and R.C. Johanson. 1997. Hydrological Simulation Program - FORTRAN, User's Manual for Version 11. EPA/600/R-97/080. Athens, GA: US Environmental Protection Agency, National Exposure Research Laboratory. Bockus, W.W., J.A. Appel, R.L. Bowdwn, A.K. Fritz, B.S. Gill, T.J. Martin, R.G. Sears, D.L. Seifers, G.L. BrownGuedira, and M.G. Eversmeyer. 2001. Success stories: Breeding for wheat disease resistance in Kansas. Plant Disease 85(5):453-461, http://dx.doi.org/10.1094/ PDIS.2001.85.5.453.

Branson, B.A. 1967. Fishes of the Neosho River system in Oklahoma. The American Midland Naturalist 78(1):126-154. 
Table 7

Concentration values and criteria reported critical for human health or aquatic ecosystems.

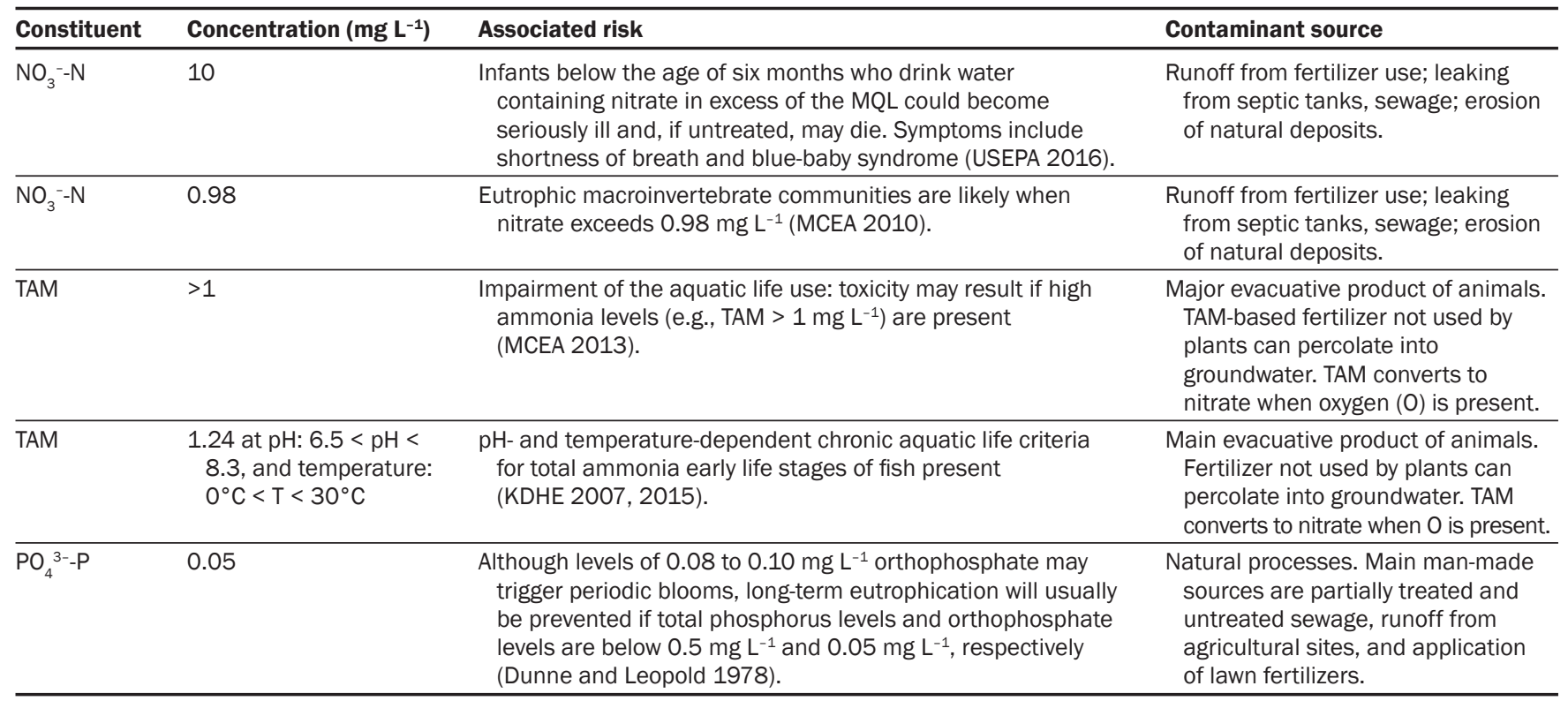

Notes: $\mathrm{NO}_{3}{ }^{-} \mathrm{N}=$ nitrate-nitrogen. $\mathrm{MQL}=$ minimum quantifiable level. $\mathrm{TAM}=$ total ammonia. $\mathrm{PO}_{4}{ }^{3-}-\mathrm{P}=$ orthophosphate.

\section{Figure 10}

Probability of exceedance. Percentage of the time that (a) nitrate-nitrogen ( $\left.\mathrm{NO}_{3}^{-}-\mathrm{N}\right)$, (b) total ammonia (TAM), and (c) orthophosphate (PO $\left.{ }_{4}^{3-}-\mathrm{P}\right)$ concentration values will exceed the established water quality criteria detailed in table 7.

(a)

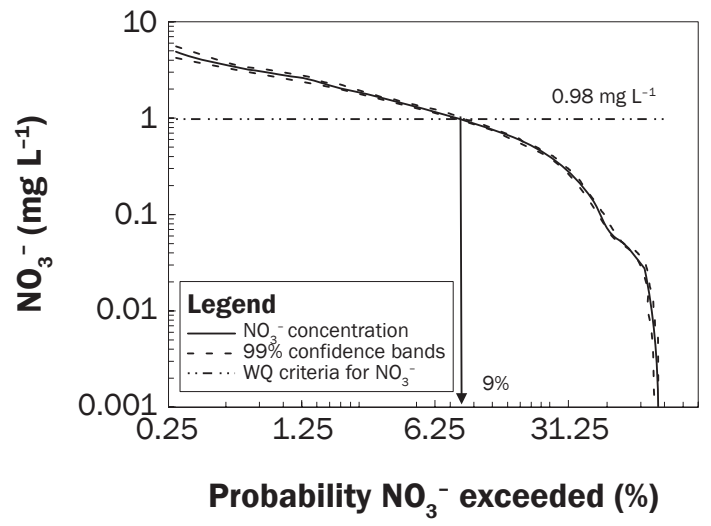

(b)

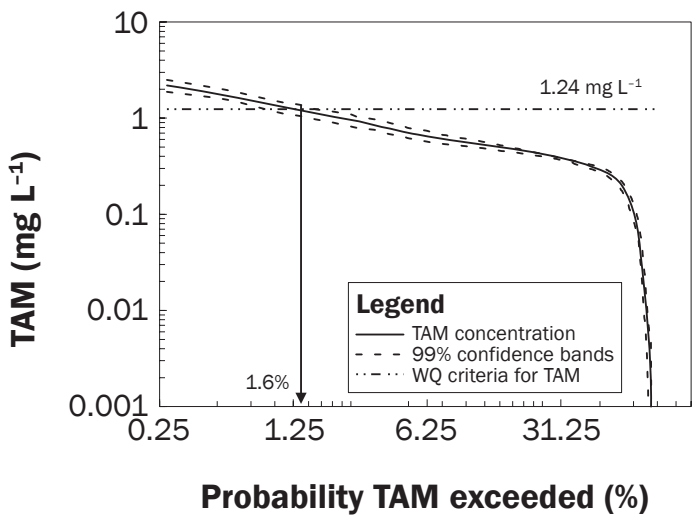

(c)

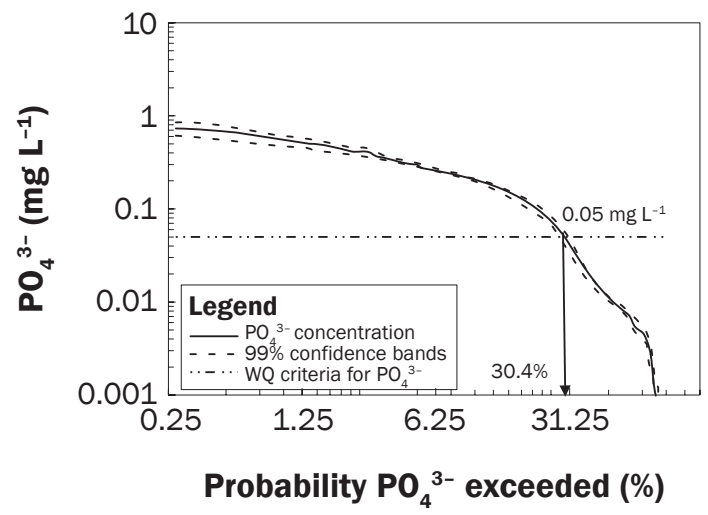




\section{Figure 11}

Relative water quality indicator (WQI) deviations from the mean WQI for each of the six subbasins conforming Cherry Creek watershed. High relative positive deviation values indicate that WQI for that particular subbasin tends to be lower than the mean WQI for the subbasin. Conversely, lower or negative relative deviations indicate that WQI for the subbasin tends to be higher than the mean WQI.

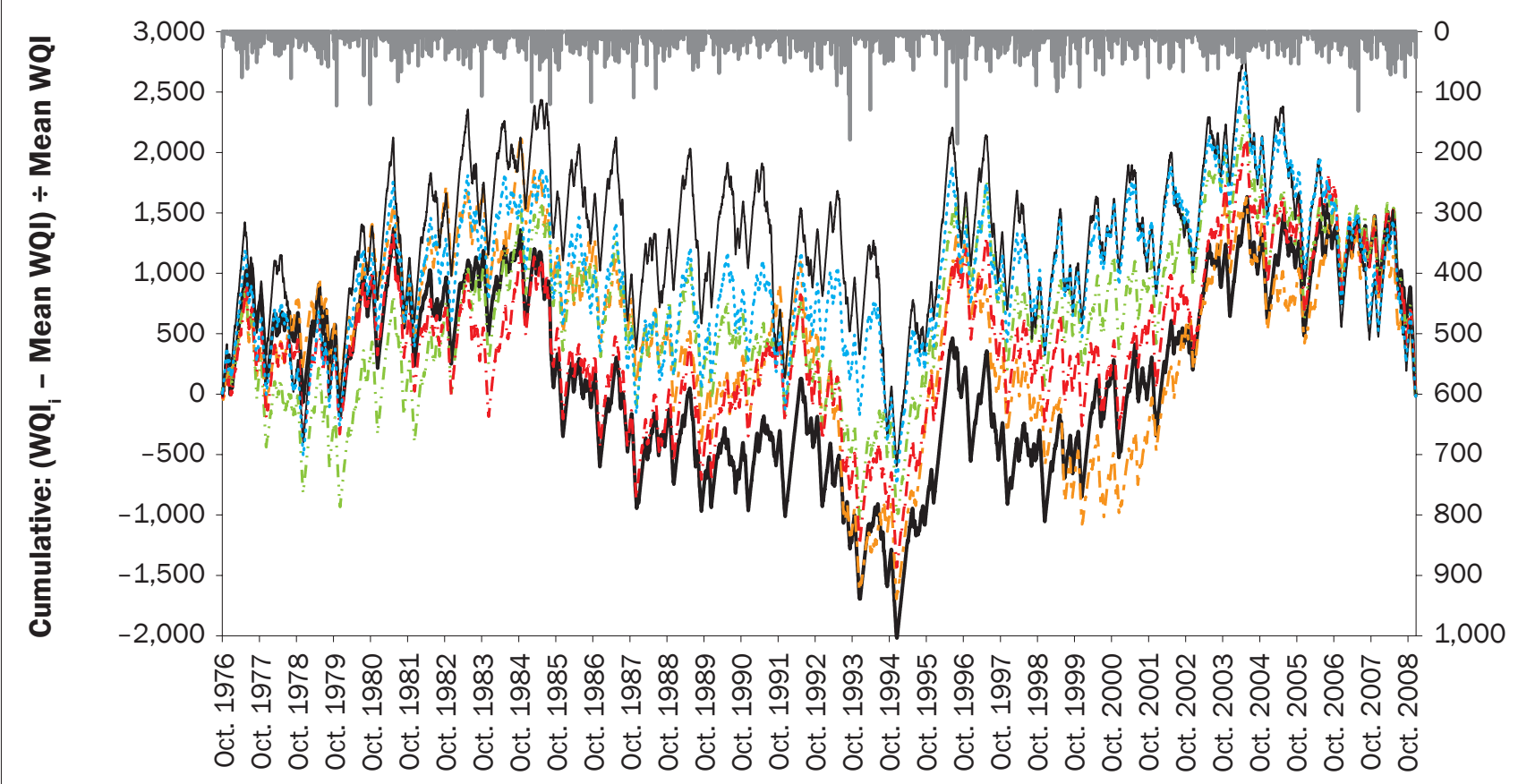

\section{Date}

\section{Legend}

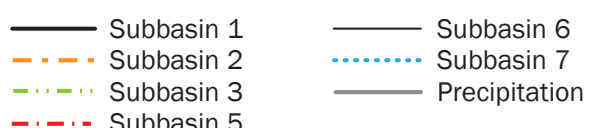

CDPH (Colorado Department of Public Health). 2015. Detection Limits. Denver, CO: Colorado Department of Public Health and Environment. http://www. coloradowaterdata.org/background_2013/fin/2013_ AWQMS_GS_materials/ReportingDetectionLimitsReg85_030115.pdf.

City of Tulsa v. Tyson Foods, Inc. 2003. 258 F. Supp. 2d 1263 (N.D. Okla. 2003). US District Court for the Northern District of Oklahoma 258 F. Supp. 2d 1263 (N.D. Okla. 2003), March 14, 2003.

DeLaune, P.B., B.E. Haggard, T.C. Daniel, I. Chaubey, and M.J. Cochran. 2006. The Eucha/Spavinaw phosphorus index: A court mandated index for litter management. Journal of Soil and Water Conservation 61(2):96-105.

Dong, Z., R.A. Lynch, and L.A. Schaider. 2016. Key contributors to variations in fish mercury within and among freshwater reservoirs in Oklahoma, USA. Environmental Sciences: Processes and Impacts $18(2): 222-236$.

Dunne, T., and L.B. Leopold. 1978. Water in Environmental Planning, 1st edition, 818. New York:W.H. Freeman and Co.

GLCWAF (Grand Lake O' the Cherokees Watershed Alliance Foundation). 2008. Grand Lake Watershed
Plan for improving water quality throughout the Grand Lake Watershed. Draft. Grove, OK: Grand Lake O' the Cherokees Watershed Alliance Foundation. http://www. ok.gov/conservation/documents/Grand_Lake_\%20 WBP_DRAFT.pdf.

Homer, C., J. Dewitz, J. Fry, M. Coan, N. Hossain, C. Larson, N. Herold, A. McKerrow, J.N. VanDriel, and J. Wickham. 2007. Completion of the 2001 National Land Cover Database for the conterminous United States. Photogrammetric Engineering and Remote Sensing 73(4):337-341. http://www.mrlc.gov/nlcd2001.php.

Hummel, P., J. Kittle, Jr., and M. Gray. 2001. WDMUtil Version 2.0, A Tool for Managing Watershed Modeling Time-Series Data User's Manual, Contract No. 68-C98-010, Work Assignment No. 2-05. Decatur, GA: Aqua Terra Consultants.

IPCC (Intergovernmental Panel on Climate Change). 2007. Climate Change 2007: The Physical Science Basis, eds. S. Solomon, D. Qin, M. Manning, Z. Chen, M. Marquis, K.B. Averyt, M. Tignor, and H.L. Mille. Cambridge, UK: Cambridge University Press.

Jin, S., L. Yang, P. Danielson, C. Homer, J. Fry, and G. Xian. 2013. A comprehensive change detection method for updating the National Land Cover Database to circa 2011. Remote Sensing of Environment 132:159-175. Juracek, K.E. 2008. Sediment storage and severity of contamination in a shallow reservoir affected by historical lead and zinc mining. Environmental Geology 54(7):1447-1463.

KDHE (Kansas Department of Health and Environment). 2002. Neosho Basin Total Maximum Daily Load.Topeka, KS: Kansas Department of Health and Environment. http://www.kdheks.gov/tmdl/ne/CherryCr_DO.pdf.

KDHE. 2007. Guidelines for investigating and remediating nitrate/ammonia contamination from agricultural chemical releases. Kansas Bureau of Environmental Remediation/Remedial Section Policy. BER policy \#BER-RS-050 (January 2007). Topeka, KS: Kansas Department of Health and Environment. http://www. kdheks.gov/ber/policies/BER_RS_50.pdf.

KDHE. 2015. Kansas surface water quality standards: Tables of numeric criteria. Topeka, KS: Kansas Department of Health and Environment, Bureau of Water. http://www. kdheks.gov/water/download/tables_of_numeric_ criteria.pdf. 


\section{Figure 12}

Minimum, first quartile, median, third quartile, and maximum water quality indicator (WQI) per subbasin. Water quality is shown to be mostly fair to excellent through time in all subbasins.

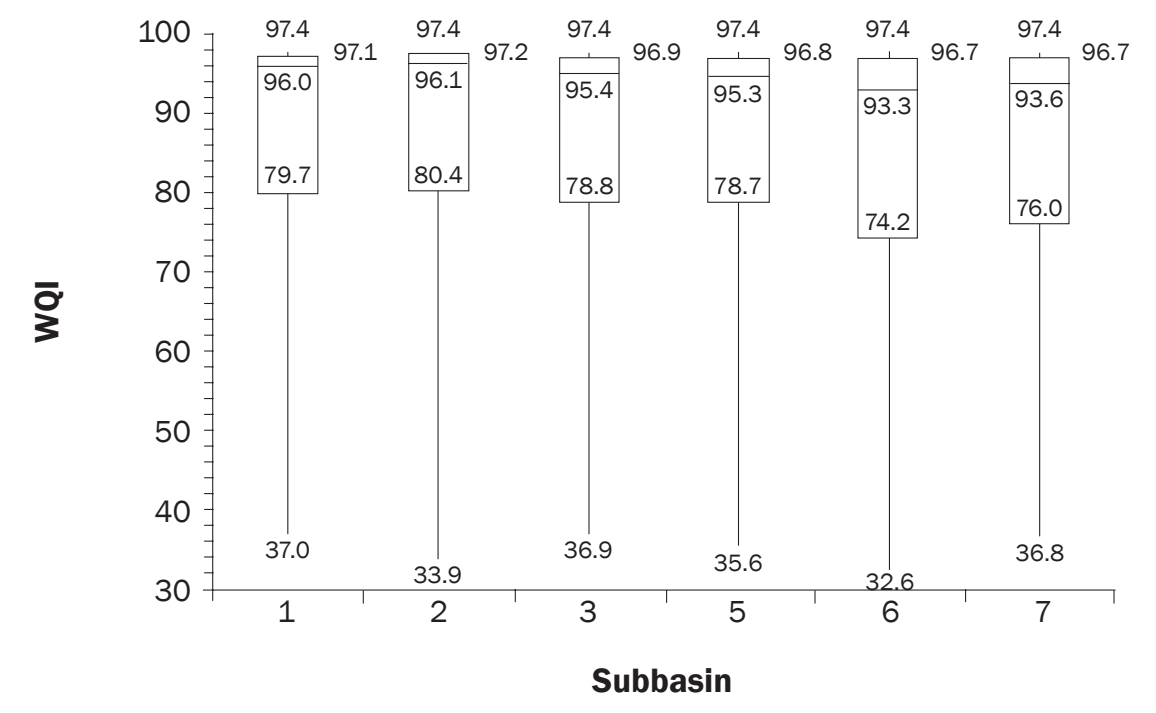

KDHE. 2017a. Neosho Basin Total Maximum Daily Load. Topeka, KS: Kansas Department of Health and Environment. http://www.kdheks.gov/tmdl/ne/ CherryCr_DO.pdf.

KDHE. 2017b. Low Dissolved Oxygen Monitoring Sites in Southeast Kansas. Topeka, KS: Kansas Department of Health and Environment. http://www.kdheks. gov/tmdl/download/eval_assessment/SE_KS_ LowDissolvedOxygen.pdf.

Kittle, J.L., Jr., A.M. Lumb, P.R. Hummel, P.B. Duda, and M.H. Gray. 1998. A tool for the generation and analysis of model simulation scenarios for watersheds ( $\mathrm{GenS} \mathrm{cn})$ : US Geological Survey Water-Resources Investigations Report 98-4134.Washington, DC: US Geological Survey. Leikam, D.F., R.E. Lamond, and D.B. Mengel. 2003. Soil Test Interpretations and Fertilizer Recommendations. Kansas State University, MF-2586. Manhattan, KS: Kansas State University Agricultural Experiment Station and Cooperative Extension Service. http://www.bookstore. ksre.ksu.edu/pubs/MF2586.pdf.

Li, Z., M. Liu, Y. Zhao, T. Liang, J. Sha, and Y. Wang. 2014. Application of regional nutrient management model in Tunxi catchment: In support of the trans-boundary ecocompensation in eastern China. Clean Soil, Air, Water 42:1729-1739, doi:10.1002/clen.201300380.

Manders, G.C., and J.S. Aber. 2014. Tri-State Mining District legacy in northeastern Oklahoma. Emporia State Research Studies 49(2):29-51. http://academic. emporia.edu/esrs/vol49/manders_aber.pdf.

MCEA (Minnesota Center for Environmental Advocacy). 2010. Minnesota Nutrient Criteria Development for Rivers. St. Paul, MN: Minnesota Pollution Control Agency. https://www.pca.state.mn.us/sites/default/ files/wq-s6-08.pdf.
MCEA. 2013. Numeric nutrient standards for rivers and streams: Part IB. St. Paul, MN: Minnesota Pollution Control Agency. https://www.pca.state.mn.us/sites/ default/files/wq-rule4-08g.pdf.

McKinney, D.C. 2011. Transboundary water challenges: Case studies. Prepared for US Department of State, Foreign Service Institute, and University of Texas at Austin. Austin, TX: University of Texas at Austin Center for Research in Water Resources. http://www. caee.utexas.edu/prof/mckinney/ce397/readings/ transboundarywaterissues.pdf.

Mignogna, L.J., W.A. Runyon, R.W. Nairn, and W.H. Strosnider. 2012. Preliminary assessment of floodplain soil metal concentrations, Neosho River, Oklahoma, 379-388. 29th Annual National Conference of the American Society of Mining and Reclamation, June 8-15, 2012, Tupelo, Mississippi.

MNW (Middle Neosho Watershed). 2011. Middle Neosho-9 Element Watershed Plan Summary. Topeka, KS: Kansas Watershed Restoration and Protection Strategy. http://www.kswraps.org/files/attachments/ middleneosho_plansummary.pdf.

MRLC (Multi-Resolution Land Characteristics Consortium). 2016. National Land Cover Dataset 1992 (NLCD1992). https://www.mrlc.gov/nlcd92_data.php.

Moriasi, D.N., J.G. Arnold, M.W. Van Liew, R.L. Bingner, R.D. Harmel, and T.L. Veith. 2007. Model evaluation guidelines for systematic quantification of accuracy in watershed simulations. Transactions of the American Society of Agricultural and Biological Engineers 50(3):885-900.

Moriasi, D.N., and P.J. Starks. 2010. Effects of the resolution of soil dataset and precipitation dataset on SWAT 2005 streamflow calibration parameters and simulation accuracy. Journal of Soil and Water Conservation 65(2):63-78, doi:10.2489/jswc.65.2.63.

Ouyang, Y., T.D. Leininger, and M. Moran. 2013. Impacts of reforestation upon sediment load and water outflow in the Lower Yazoo River Watershed, Mississippi. Ecological Engineering 61:394-406.

Ouyang,Y., T.D. Leininger, and M. Moran. 2015. Estimating effects of reforestation on nitrogen and phosphorus load reductions in the Lower Yazoo River Watershed, Mississippi. Ecological Engineering 75:449-456.

OWRB (Oklahoma Water Resources Board). 2001. Segregating water quality degradation of Grand Lake between tributaries and land use features. Oklahoma City, OK: State of Oklahoma Water Resources Board. https://www.owrb.ok.gov/studies/reports/reports_ pdf/GrandLakeTribReport-v1-2a.pdf.

Padedda, B.M., N. Sechi, G.G. Lai, M.A. Mariani, S. Pulina, C.T. Satta, A.M. Bazzoni, T. Virdis, P. Buscarinu, and A. Lugliè. 2015. A fast-response methodological approach to assessing and managing nutrient loads in eutrophic Mediterranean reservoirs. Ecological Engineering $85: 47-55$.

Parajuli, P., P. Jayakody, G.F. Sassenrath, Y. Ouyang, and J.W. Pote. 2013. Assessing the impacts of crop-rotation and tillage on crop yields and sediment yield using a modeling approach. Agricultural Water Management 119:32-42.

Pierce, FJ., W.E. Larson, R.H. Dowdy, and W.A.P. Graham. 1983. Assessing long-term changes due to erosion. Journal of Soil and Water Conservation 38(1):39-44.

Pimentel, D. 2006. Soil erosion: A food and environmental threat. Environment, Development and Sustainability 8:119-137.

Reilly,J.F.,A.J. Horne, and C.D. Miller. 1999. Nitrate removal from a drinking water supply with large free-surface constructed wetlands prior to groundwater recharge. Ecological Engineering 14(1-2):33-47.

Searcy, J.K. 1959. Flow-Duration Curves. Manual of Hydrology: Part 2. Low-Flow Techniques. Geological Survey Water-Supply Paper 1542-A. Washington, DC: US Government Printing Office. http://pubs.usgs.gov/ wsp/1542a/report.pdf.

Terrado, M., E. Borrell, S. de Campos, D. Barcelo, and R. Tauler. 2010. Surface-water-quality indices for the analysis of data generated by automated sampling networks. Trends in Analytical Chemistry 29(1):40-52.

Tomer, M.D., S.A. Porter, D.E. James, K.M.B. Boomer, J.A. Kostel, and E. McLellan. 2013. Combining precision conservation technologies into a flexible framework to facilitate agricultural watershed planning. Journal of Soil and Water Conservation 68(5):113A-120A, doi:10.2489/jswc.68.5.113A

Tomlinson, P.J., M.C. Savin, and P.A. Moore, Jr. 2015. Longterm applications of untreated and alum-treated poultry litter drive soil nitrogen concentrations and associated microbial community dynamics. Biology and Fertility of Soils 51(1):43-55. 
Tomlinson, P.J., D. Shoup, and D. Ruiz Diaz. 2014. Poultry litter: Nutrient availability, value, and storage practices. K-State Extension Agronomy eUpdate. 486. Manhattan, KS: Kansas State University. https://webapp.agron.ksu. edu/agr_social/eu_article.throck?article_id $=406$.

USEPA (US Environmental Protection Agency). 2002. Total Maximum Daily Load (TMDL) Report: TMDL Document for Cherry Creek. TMDL ID: 3522. Washington, DC: US Environmental Protection Agency. http://iaspub.epa.gov/waters10/ attains_impaired_waters.tmdl_report?p_tmdl_ id $=3522 \&$ p_tribe $=\&$ p_report_type $=$.

USEPA. 2006. IDL-MDL-PQL. Region III Quality Assurance Factsheet. Washington, DC: US Environmental Protection Agency. https://www.epa. gov/sites/production/files/2015-06/documents/ whatthel.pdf.

USEPA. 2008. BASINS Technical Note 10: Using the BASINS Meteorological Database (Version 2006). Washington, DC: Office of Water of the US Environmental Protection Agency, Document 4305. https://www.epa.gov/sites/production/files/2015-08/ documents/2009_04_13_basinss_tecnote10.pdf.

USEPA. 2010. Limits below Quantification Levels: Permit guidance 9. Statutory reference: ORC 6111.13. Rule reference: OAC 3745-33-07(C), November 8, 2010. Columbus, OH: Ohio EPA, Division of Surface Water.

USEPA. 2013. Better Assessment Science Integrating Point and Nonpoint Sources (BASINS). Research Triangle Park, NC: National Exposure Research Laboratory. http://water.epa.gov/scitech/datait/models/basins/ index.cfm.

USEPA. 2016. Table of Regulated Drinking Water Contaminants. Drinking Water Contaminants: Standards and Regulations. Washington, DC: US Environmental Protection Agency. http://www. epa.gov/your-drinking-water/table-regulateddrinking-water-contaminants.

USGS (US Geological Survey). 2014. NLCD 2001 to 2011 Land Cover Change Pixels (2011 edition, amended 2014). National Geospatial Data Asset (NGDA) Land Use Land Cover. Sioux Falls, SD: US Geological Survey. http://www.mrlc.gov.

Wayman, C., E. Gordon, and G. King. 1999. The Method Detection Limit and Practical Quantitation Level: Their Derivations and Regulatory Implications. 1999 Waste Management Symposia. http://www.wmsym.org/ archives/1999/12/12-5.pdf.

Wouters, P.2013.International Law-FacilitatingTransboundary Water Cooperation. TEC Background Papers. No. 17. Stockholm, Sweden: Global Water Partnership. https://ssrn. com $/$ abstract $=2363809$. 